\title{
In Vitro Microbiological and Drug Release of Silver/Ibuprofen Loaded Wound Dressing Designed for the Treatment of Chronically Infected Painful Wounds
}

\author{
Alejandra Mogrovejo-Valdivia ${ }^{1}$, Mickael Maton ${ }^{1}$, Maria Jose Garcia-Fernandez ${ }^{1}$, Nicolas Tabary ${ }^{2} \mathbb{D}$, Feng Chai ${ }^{1}$, \\ Christel Neut $^{3}{ }^{(D}$, Bernard Martel ${ }^{2}$ and Nicolas Blanchemain ${ }^{1, *}$ \\ 1 U1008 Advanced Drug Delivery Systems, Institut National de la Santé et de la Recherche Médicale (INSERM), \\ Centre Hospitalier Régional Universitaire de Lille (CHU Lille), University of Lille, 59000 Lille, France; \\ amvaldivia26@gmail.com (A.M.-V.); mickael.maton@univ-lille.fr (M.M.); \\ maria-jose.garcia-fernandez@univ-lille.fr (M.J.G.-F.); feng.hildebrand@univ-lille.fr (F.C.) \\ 2 UMR 8207, UMET-Unité Matériaux et Transformations, Centre National de la Recherche \\ Scientifique (CNRS), Institut National de la Recherche Agronomique (INRA), Ecole Nationale Supérieure de \\ Chimie de Lille (ENSCL), University of Lille, 59655 Lille, France; nicolas.tabary@univ-lille.fr (N.T.); \\ bernard.martel@univ-lille.fr (B.M.) \\ 3 U1286 INFINITE-Institute for Translational Research in Inflammation, Institut National de la Santé et de la \\ Recherche Médicale (INSERM), Centre Hospitalier Régional Universitaire de Lille (CHU Lille), University of \\ Lille, 59000 Lille, France; christel.neut@univ-lille.fr \\ * Correspondence: nicolas.blanchemain@univ-lille.fr; Tel.: +33-32-062-6975; Fax: +33-32-062-6854
}

Citation: Mogrovejo-Valdivia, A.; Maton, M.; Garcia-Fernandez, M.J.; Tabary, N.; Chai, F.; Neut, C.; Martel, B.; Blanchemain, N. In Vitro Microbiological and Drug Release of Silver/Ibuprofen Loaded Wound Dressing Designed for the Treatment of Chronically Infected Painful Wounds. Antibiotics 2021, 10, 805. https://doi.org/10.3390/ antibiotics 10070805

Academic Editor: Catherine Mullié

Received: 3 June 2021

Accepted: 29 June 2021

Published: 2 July 2021

Publisher's Note: MDPI stays neutral with regard to jurisdictional claims in published maps and institutional affiliations.

Copyright: (c) 2021 by the authors. Licensee MDPI, Basel, Switzerland. This article is an open access article distributed under the terms and conditions of the Creative Commons Attribution (CC BY) license (https:// creativecommons.org/licenses/by/ $4.0 /)$.

Abstract: This study consisted of developing a dressing loaded with silver (Ag) and ibuprofen (IBU) that provides a dual therapy, antibacterial and antalgic, intended for infected painful wounds. Therefore, non-woven polyethyleneterephtalate (PET) textiles nonwovens were pre-treated by cyclodextrin crosslinked with citric acid by a pad/dry/cure process. Then, textiles were impregnated in silver solution followed by a thermal treatment and were then coated by Layer-by-Layer (L-b-L) deposition of a polyelectrolyte multilayer (PEM) system consisting of anionic water-soluble poly(betacyclodextrin citrate) (PCD) and cationic chitosan. Finally, ibuprofen lysinate (IBU-L) was loaded on the PEM coating. We demonstrated the complexation of IBU with native $\beta C D$ and PCD by phase solubility diagram and ${ }^{1} \mathrm{H}$ NMR. PEM system allowed complete IBU-L release in $6 \mathrm{~h}$ in PBS pH 7.4 batch (USP IV). On the other hand, microbiological tests demonstrated that loaded silver induced bacterial reduction of $4 \log _{10}$ against $S$. aureus and $E$. coli and tests revealed that ibuprofen lysinate loading did not interfere with the antibacterial properties of the dressing.

Keywords: wound dressing; antibacterial; anti-inflammatory; drug delivery system; layer by layer; cyclodextrins

\section{Introduction}

Chronic wounds represent a major public health problem. It is estimated that, in developed countries, 1 to $2 \%$ of the population will suffer a chronic wound during their lifetime [1]. Among chronic wounds, leg ulcers, burns or bedsores present an infectious risk, causing excessive inflammation that delays the healing process associated with severe pain and affect psychologic state of patients. Discomfort due to excessive pain, isolation, stress and depression negatively affect the immune system of patients thus increasing healing time. Hence, it is of first importance to treat chronic wounds at the earliest by using effective therapies [2-4].

An option to treating infected wounds is the use of technical dressings to provide specific therapies. Currently on the market, there is a wide range of dressings. They consist of different biomaterials and are sometimes combined with active substances to provide specific therapies depending on the etiology of the wound. Among these dressings, silverbased dressings are widely used to treat wounds that are infected or at risk of infection. 
Several research works have shown the in vitro antibacterial efficacy of silver for infected wounds treatment [5-11]. Nevertheless, silver presents toxic effects on keratinocytes and fibroblasts inhibiting their proliferation [12-14]. Despite this drawback, clinical studies demonstrated the efficacy of commercial silver-based wound dressings on the treatment of chronic leg ulcers, reporting a $45-56 \%$ of wound size reduction after 4 weeks $[15,16]$.

However, the presence of silver in the dressings does not address the problem of excessive inflammation produced by these infected wounds and delaying the healing process. Nonsteroidal anti-inflammatory drugs (NSAIDs) are commonly used to treat inflammation, pain, swelling and fever. Ibuprofen is the most frequently used NSAID drug, it is a non-selective inhibitor of cyclooxygenase (COX-2), an enzyme that is responsible for prostaglandin synthesis [17]. However, the systematic administration of ibuprofen may cause side effects, such as a decrease of renal functions or gastrointestinal bleeding [3]. As a matter of fact, clinical studies carried out by Jorgensen et al., [18] Gottrup et al., [2] and Sibbald et al., [19] demonstrated that the use of dressings containing ibuprofen (Bitain ${ }^{\circledR}$-Ibu, Coloplast A/S, Humlebaek, Denmark) reduces pain significantly, without compromising the wound healing process, due to ibuprofen local release.

In recent years, surface treatment techniques have been developed to improve the performance of wound dressings. Techniques, such as encapsulation, fiber coating, chemical or physical grafting are wide strategies used for the incorporation of active ingredients onto dressings supports. Among these technics, fiber coating with polyelectrolyte multilayer (PEM) is really attractive to obtain a multidrug delivery systems $[8,10,20-24]$. PEM is based on the alternative deposition of positive and negative polyelectrolytes on a substrate, through electrostatic interactions, resulting in the superposition of self-assembled polyelectrolyte layers [25]. Many types of polyelectrolytes; natural, synthetic or semi-synthetic, can be used to develop PEM systems for drug delivery wound dressings. Maver et al. [21], used alginate and viscose for the release of lidocaine and diclofenac; poly $(\beta$-amino ester)/alginate or chondroitin sulfate were used to obtain controlled release properties toward vancomycin and diclofenac [22,24]. Polyelectrolytes complexes formed by chitosan/phosvitin, alginate or hyaluronic acid were employed for the release of antimicrobial peptides and silver nanoparticles [9,26-28].

Chitosan (CHT) is a polysaccharide obtained from the deacetylation of chitin extracted from crustacean, yeasts and algae. CHT is composed of D-2-deoxy-2-acetylglucosamine and D-2-deoxy-glucosamine units linked by $\beta(1,4)$ binding [29]. CHT is of many interest in the biomedical field, particularly for wound healing, due to its biodegradability and biocompatibility character [30], its antimicrobial [29-31], moisturizing [30], hemostatic [32], and analgesic [29-31,33] properties; which are directly related to its cationic character and the size of the polymer chain [31]. In addition, when CHT is prepared in acidic media, a protonation of amino groups occurs and gives to $\mathrm{CHT}$ the character of a positive polyelectrolyte fully adapted for the development of a PEM system $[28,34,35]$. Because of these features, several CHT-based dressings have been developed in the form of fibers, hydrogels, membranes or scaffolds [30].

Cyclodextrins (CDs) are cyclic oligosaccharides contained glucopyranose units joined together by $\alpha-1,4$ glycosidic bonds. The most commonly used CDs are $\alpha-C D, \beta-C D$ and $x-$ CD presenting 6, 7 and 8 glucose units respectively [36]. CDs have a truncated cone-shaped 3D structure; their cavity has a hydrophobic character which allows forming inclusion complexes with a large variety of lipophilic molecules, and works as drug carriers to obtain sustained drug delivery systems [23,37-43]. Furthermore, CDs can undergo chemical modifications in order to enhance their solubilizing power. Anionic cyclodextrins polymers (PCD) increase still more the solubility of active ingredients because of the cooperative action between CDs cavities and the polymeric network [44].

Our team has worked for several years on the formation of polyelectrolyte complexes between CHT and PCD for the formation of hydrogel, nanofibers and PEM system. The cytocompatibility and hemocompatibility of the combination of these polyelectrolyte complexes has been widely demonstrated [45-47]. Recently, our group has reported the 
development of a wound dressing covered by a PEM system formed by chitosan (CHT) as a positive polyelectrolyte and $\beta$-cyclodextrin polymer (PCD) as an anionic polyelectrolyte for the sustained release of silver and thus avoid toxicity on keratinocytes and fibroblasts. The objective of this work was to benefit from the PEM coating as a protective layer that would reduce silver diffusion in the wound without losing its antibacterial activity. We have observed that the PEM coating allowed a sustained release of silver $(4 \%$ of silver released at $72 \mathrm{~h}$ ) without affecting the antibacterial activity against $S$. aureus and E. coli. [10].

The aim of the present work was to develop a wound dressing containing two active compounds; silver sulfate as an antibacterial agent, and ibuprofen as a pain reliever. This paper focused the ibuprofen performance onto dressings, thanks to cyclodextrins properties to form inclusion complexes with drugs. With this purpose, a PEM system formed by CHT/PCD was applied to provide a sustained release for both drugs. For this, a PET nonwoven fabric was pre-treated by $\beta C D$ crosslinked with citric acid by a pad/dry/cure process in order to obtain an anionic layer for then load silver on the support. After this, a CHT/PCD system was build-up using the dip-coating method until 21 layers were formed. Finally, ibuprofen was incorporated on the dressing by the soaking method. The interaction between ibuprofen and $\beta$-cyclodextrin polymer was assessed by ${ }^{1} \mathrm{H}$ NMR and phase solubility diagrams, the in vitro ibuprofen release was analyzed in batch conditions and the antibacterial properties of final dressing was evaluated using Kirby Bauer and Kill time tests.

\section{Materials and Methods}

\subsection{Materials and Reagents}

A non-woven polyethylene terephthalate textile (PET) was used as a textile support. PET textile (NSN 365) was provided by PGI Nordlys (Bailleul, France). PET textile surface weight is $65 \mathrm{~g} / \mathrm{m}^{2}$ and thickness is $0.186 \mathrm{~mm}$ respectively.

Chitosan (CHT) was purchased from Sigma Aldrich (Saint-Quentin Fallavier, France). CHT presents a low molecular weight $\left(140 \mathrm{~kg} \cdot \mathrm{mol}^{-1}\right)$, a viscosity of $146 \mathrm{cp}$ at a concentration of $1 \% w / v$ (in acetic acid solution $1 \% v / v$ ) and a degree of deacylation (DD) of $77 \%$ (according to the supplier).

$\beta$-cyclodextrin $(\beta C D)$ was provided from Roquette (Kleptose ${ }^{\circledR}$, Lestrem, France) and the anionic water-soluble $\beta$-cyclodextrin polymer (PCD) was synthetized according the method described by Weltrowski et al. [48]. Briefly, citric acid, sodium hypophosphite and $\beta C D$ s were solubilized in respective weight ratios of $10 \mathrm{~g} / 3 \mathrm{~g} / 10 \mathrm{~g}$ in $100 \mathrm{~mL}$ of water. After water removal, the solid mixture was cured at $140{ }^{\circ} \mathrm{C}$ during $30 \mathrm{~min}$ under vacuum. Water was then added, the suspension was filtered, and then dialyzed for $72 \mathrm{~h}$ using 6 to $8 \mathrm{kDa}$ membranes (Spectra Por 1, Spectrumlabs). Finally, PCD was recovered by freeze drying. The polymer, poly(cyclodextrin citrate) contained $50 \%$ in weight of $\beta$-cyclodextrin, $4 \mathrm{mmol}$ per gram of $\mathrm{COOH}$ groups (measured by acid-base titration) and the molecular mass was 20,000 g/mol (measured by Size Exclusion Chromatography combined with multi angle light scattering SEC-MALS).

Silver sulfate was provided from Sigma Aldrich (Saint-Quentin Fallavier, France). Silver sulfate $\left(\mathrm{Ag}_{2} \mathrm{SO}_{4}\right.$, purity $\left.\geq 99 \%\right)$ was chosen as antibacterial agent. Ibuprofen was used in this work as an anti-inflammatory drug. Ibuprofen (IBU) was purchased from INRESA (Bartenheim, France), it presents a molecular weight of $206.28 \mathrm{~g} \cdot \mathrm{mol}^{-1}$ and a water solubility of $21 \mathrm{mg} / \mathrm{L}$ at $25^{\circ} \mathrm{C}$. Ibuprofen lysinate (IBU-L) is a racemic form of ibuprofen and lysine salt. IBU-L was provided from BASF France (Levallois-Perret, France), IBU-L presents a molecular weight of $352.48 \mathrm{~g} \cdot \mathrm{mol}^{-1}$ and a water solubility of $35 \mathrm{~g} / \mathrm{L}$. The diagram of solubility and proton NMR were performed with IBU to determine the constant of affinity and the geometry of inclusion complex. Drug sorption onto textile was performed with IBU-L, a soluble form of IBU in order to optimize the loading of ibuprofen onto the textiles. 


\subsection{Development of Antibacterial Dressing}

Pre-treatment of PET by pad-dry-cure with $\beta$-cyclodextrin and citric acid (Figure 1, Step 1-4)): Surface modification of PET supports was applied preliminarily to silver loading and layer-by-layer $(L-b-L)$ deposition. The way for providing anionic character to the nonwoven fibers is by modifying fibers with carboxylate groups issued from the reaction between citric acid (CTR) and $\beta$-cyclodextrin $(\beta C D)$ using the pad/dry/cure process as a previously reported by our laboratory $[10,37,49-52]$.

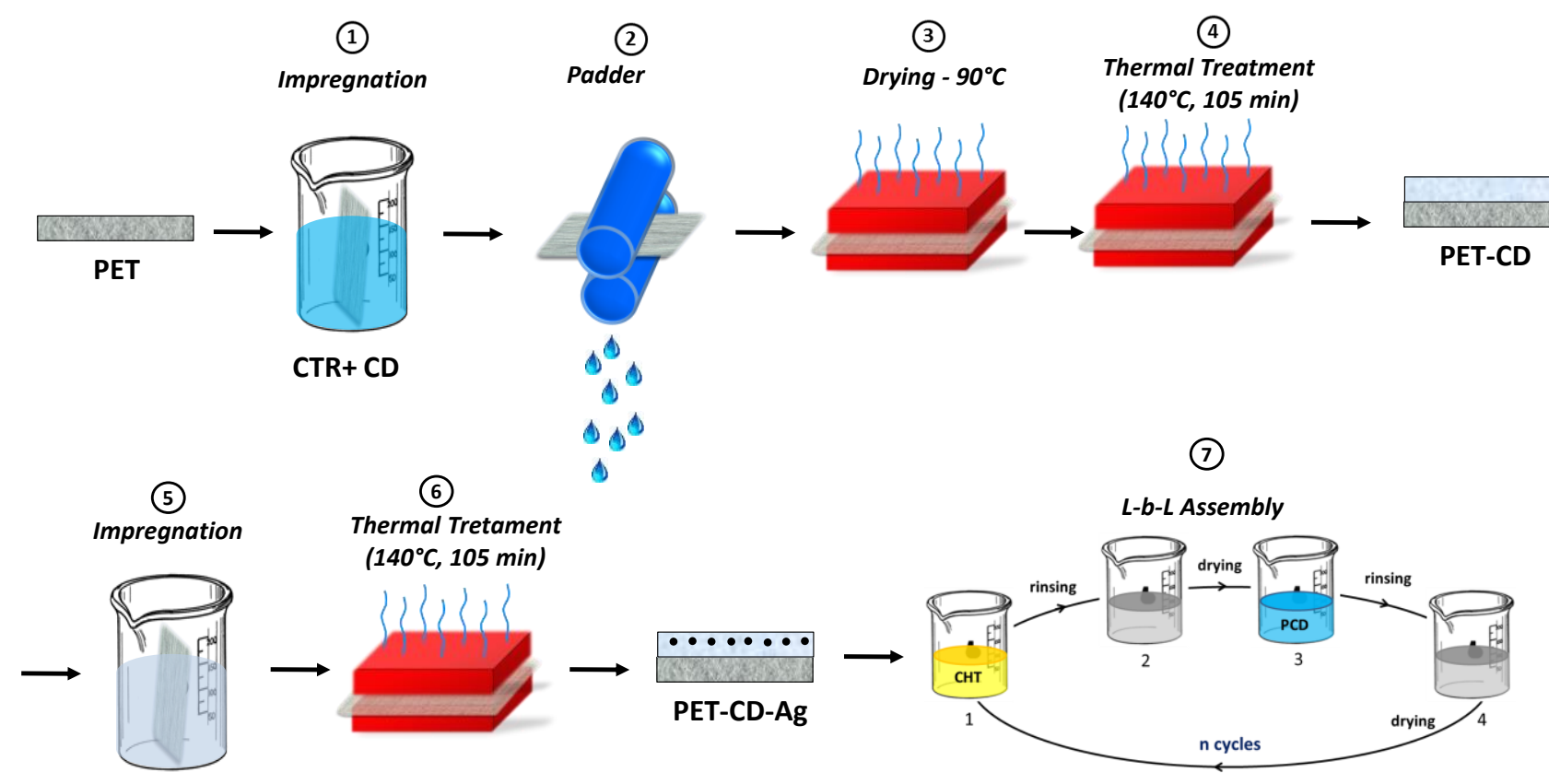

Silver sufate

(8)

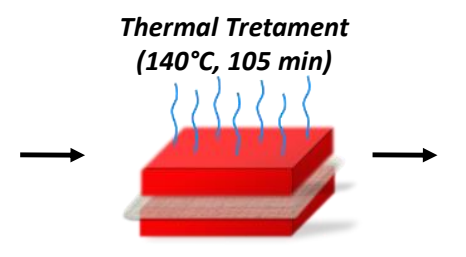

(9) Impregnation

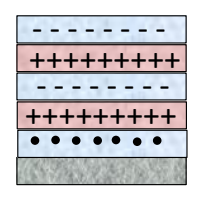

PET-CD-Ag-PEM

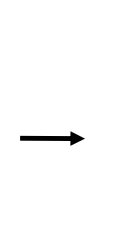

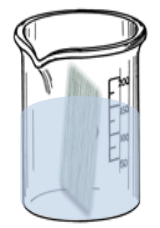

IBU-L

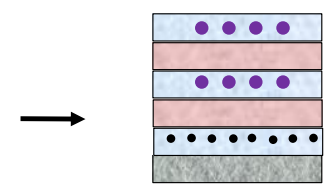

PET-CD-Ag-PEM-IBU

Figure 1. Schematization of preparation of PET-CD-Ag-PEM-IBU.

In order to remove the sizing agent, raw PET textile supports were preliminarily washed three times by Soxhlet extractor with isopropanol $(3 \mathrm{~h})$ and rinsed three times with ultrapure water, then dried during $15 \mathrm{~min}$ at $90^{\circ} \mathrm{C}$.

Aqueous solution of citric acid as crosslinking agent (CTR, 10\% w/v) and sodium hypophosphite as catalyst $\left(\mathrm{NaH}_{2} \mathrm{PO}_{2}, 1 \% w / v\right)$ were prepared. $\beta \mathrm{CD}(10 \% w / v)$ was dissolved in the citric acid solution. Weighed raw PET samples $(25 \mathrm{~cm} \times 25 \mathrm{~cm})$ were then padded in the final solution, roll-squeezed (roll speed $1 \mathrm{~m} / \mathrm{min}, 2$ bars) (ROACHES, Birstall, England), dried at $90{ }^{\circ} \mathrm{C}$ for $15 \mathrm{~min}$ and cured at $140{ }^{\circ} \mathrm{C}$ in a ventilated oven (Minithermo, Roaches, Birstall, England) for $30 \mathrm{~min}$ in the case of the $\beta \mathrm{CD}$. This curing step provoked the crosslinking reaction between $\beta C D$ with citric acid. Functionalized textiles were washed with ultrapure water three times for $20 \mathrm{~min}$ under ultrasound. Finally, after washing, all textiles samples were dried at $90{ }^{\circ} \mathrm{C}$ for $15 \mathrm{~min}$. These thermo-fixed primer layer on PET composed of poly(cyclodextrin citrate) were conventionally named as layer \#1 on both supports types named respectively PET-CD. Finally, in order to transform residual carboxylic groups $(\mathrm{COOH})$ carried by citrate crosslinks into carboxylate groups $\left(\mathrm{COO}^{-}\right)$, 
samples were treated with a sodium carbonate solution $(4 \mathrm{~g} / \mathrm{L})$ for $15 \mathrm{~min}$ then rinsed twice with ultrapure water and finally dried for $15 \mathrm{~min}$ at $90{ }^{\circ} \mathrm{C}$.

Silver sulfate loading (Figure 1, step 5-6): Functionalized textiles were cut in samples of $5 \times 5 \mathrm{~cm}^{2}$. Silver sulfate $(10 \mathrm{~g} / \mathrm{L})$ was dissolved at $70{ }^{\circ} \mathrm{C}$ under stirring $(80 \mathrm{rpm})$ for $45 \mathrm{~min}$ and filtered with a polyethersulfone filter $\left(0.22 \mu \mathrm{m}\right.$, Millex $\left.{ }^{\circledR} \mathrm{GP}\right)$. Then, textile samples were impregnated in $65 \mathrm{~mL}$ of this solution overnight at $37^{\circ} \mathrm{C}$ under stirring (80 rpm). Samples were rinsed with ultrapure water in an ultrasonic bath for $1 \mathrm{~min}$ and then left under stirring $(80 \mathrm{rpm})$ for $4 \mathrm{~min}$ at $37^{\circ} \mathrm{C}$ for three times. Samples were dried at $90{ }^{\circ} \mathrm{C}$ for $15 \mathrm{~min}$. Finally, a thermal treatment was applied at $140{ }^{\circ} \mathrm{C}$ for $105 \mathrm{~min}$ to fixe silver into textiles.

Polyelectrolyte multilayer build-up (Figure 1, step 7-8): The PEM system was built according to the method reported by Decher $[25,53]$ using the dip-coating technique previously described by our group $[10,23,49,50]$. Samples were firstly dipped into $40 \mathrm{~mL}$ of a CHT solution $\left(0.5 \%\right.$ w/v) solubilized in acetic acid $(1 \% v / v)$ for $1 \mathrm{~min}$, dried at $90{ }^{\circ} \mathrm{C}$ for $15 \mathrm{~min}$, rinsed in acetic acid $(0.3 \% v / v)$ to remove excess of chitosan and finally dried at $90{ }^{\circ} \mathrm{C}$ for $15 \mathrm{~min}$. Then, the samples were dipped into $\beta$-cyclodextrin polymer (PCD) aqueous solution $(0.3 \% \mathrm{w} / \mathrm{v})$ for $1 \mathrm{~min}$, dried at $90{ }^{\circ} \mathrm{C}$ for $15 \mathrm{~min}$, rinsed with ultrapure water and dried at $90{ }^{\circ} \mathrm{C}$ for $15 \mathrm{~min}$. The next layers were deposited by applying these sequence 21 times, resulting in overlaying 21 bilayers [10]. A treatment at $140{ }^{\circ} \mathrm{C}$ for 105 min was finally applied for the stabilization of the PEM system. Finally, a last step consist on the impregnation in IBU-L solution to load the PEM. The final dressing samples were named PET-CD-Ag-PEM-IBU (Figure 1, step 9).

\subsection{Ibuprofen-PCD Complexation Study}

\subsubsection{Phase Solubility Diagram of Ibuprofen}

The IBU solubility study was developed according the method described by Higuchi and Connors [54]. A buffer solution $(\mathrm{KCl} 0.2 \mathrm{M}$ and $\mathrm{HCl} 0.1 \mathrm{M})$ at $\mathrm{pH} 2$ was used to prepared solutions of $\beta C D$ and PCD at different concentrations $(2 \mathrm{mM}$ to $10 \mathrm{mM}$ and $2 \mathrm{mM}$ to $44 \mathrm{mM}$ respectively). A volume of $5 \mathrm{~mL}$ of these solutions was put into flasks containing $100 \pm 5 \mathrm{mg}$ of IBU in order to obtain an excessive concentration of $20 \mathrm{~g} / \mathrm{L}$. Then, flasks were kept under stirring ( $210 \mathrm{rpm}$, room temperature) for $24 \mathrm{~h}$. Afterward, the samples were filtered through a $0.45 \mu \mathrm{m}$ cellulose membranes and analyzed by High-Performance Liquid Chromatography coupled to UV detection (HPLC/UV-Vis) (Shimadzu LC-2010AHT, Shimadzu, Japan). The parameters used were a C18 column $(3 \times 150 \mathrm{~mm})$, a mobile phase composed of acetonitrile and $\mathrm{H}_{3} \mathrm{PO}_{4}$ at $\mathrm{pH} 2.25(40: 60 \mathrm{v} / \mathrm{v})$ a flow rate of $1 \mathrm{~mL}$ and an injected volume of $20 \mathrm{~mL}$. The detector was set at $225 \mathrm{~nm}$ with a retention time of $6.5 \mathrm{~min}$.

The formation constant $\left(\mathrm{K}_{\mathrm{f}}\right)$ and the complexation efficiency $(\mathrm{CE})$ values of $\mathrm{CD} / \mathrm{IBU}$ and PCD/IBU complexes were estimated from the slope of phase solubility diagrams in the initial linear range following to the equations below:

$$
\begin{gathered}
K_{f}=\frac{\text { slope }}{S_{0}(1-\text { slope })} \\
C E=\frac{\text { slope }}{1-\text { slope }}
\end{gathered}
$$

where $S_{0}$ is the intrinsic solubility of IBU, the solubility when cyclodextrin is not present.

\subsubsection{Proton NMR Spectroscopy}

${ }^{1} \mathrm{H}$ NMR was performed to reveal the complexation between ibuprofen (IBU) and PCD. For this, IBU-PCD complex was prepared in ultrapure water in equimolar amount ( $25 \mathrm{mM}$ : $25 \mathrm{mM}$ ). The complex was then stirred $(100 \mathrm{rpm})$ at $37^{\circ} \mathrm{C}$ for $72 \mathrm{~h}$ to obtain the equilibrium and then filtered through $0.45 \mu \mathrm{m}$ Nylon ${ }^{\circledR}$ membranes, frozen and lyophilized. Finally, $10 \mathrm{mg}$ of the white powder obtained was dissolved in $1 \mathrm{~mL}$ of $\mathrm{D}_{2} \mathrm{O}$ to be analyze using a 1H NMR spectrometer Bruker AC300 high resolution $300 \mathrm{MHz}$. 
Two-dimensional NOESY (Nuclear Overhauser Effect Spectroscopy) experiments were operated at $300 \mathrm{~K}$ using the standard Bruker parameters and a spin-lock mixing time of $350 \mathrm{~ms}$ with TPPI

Method: 2D spectrum consisted of a matrix of 2048 (F2) by 2048 (F1) covering a sweep width of $1929 \mathrm{~Hz}$ and 16 increments were collected with 256 transients.

\subsection{Drug Sorption and Drug Release}

IBU-L sorption/desorption and kinetics release were obtained from wound dressings samples disks (Ø11 mm). Solutions of IBU-L were prepared at different concentrations in phosphate buffered saline (PBS) pH 7.4. HPLC/UV-Vis method was used to quantify IBU-L with the same parameters mentioned above (Section 2.3.1).

\subsubsection{Ibuprofen Sorption and Isotherms Analyses}

IBU-L loading studies were realized by the batch technique. Briefly, dressing disk samples $(n=6)$ were soaked in ibuprofen lysinate (IBU-L) solution both at $1 \mathrm{~g} / \mathrm{L}$, at room temperature at $240 \mathrm{rpm}$. These samples were named PET-CD-Ag-PEM-IBU. Desorption of loaded IBU-L was made in PBS pH 7.4 for $24 \mathrm{~h}$ under stirring respectively. The total amount of desorbed drug from dressings samples was evaluated by HPLC/UV-Vis method previously described.

For isotherms experiments, dressings disk samples were immersed in IBU-L solutions at different concentrations, following a bath ratio of $5 \mathrm{~mL}$ for each sample during $24 \mathrm{~h}$ with stirring at $240 \mathrm{rpm}$ at room temperature. Disk samples were then rinsed and analyzed by HPLC-UV/vis technique, as mentioned above, for determinate the quantity of drug loaded $\left(q e, \mathrm{mg} / \mathrm{cm}^{2}\right)$ and the concentration of the solution at the equilibrium $(\mathrm{Ce}, \mathrm{mg} / \mathrm{L})$, calculated from qe.

Two adsorption isotherms models are proposed to understand the adsorption mechanism that are obtained from linearly forms. On one hand, Langmuir isotherm refers the adsorption sites with identical energy, a single molecule by adsorption site and no interaction between ibuprofen molecules, the adsorption is carried out in a monolayer.

$$
\frac{C e}{q e}=\frac{1}{K_{L}}+\frac{L C e}{K_{L}}
$$

where $K_{L}(\mathrm{~L} / \mathrm{g})$ and $\alpha L$ are the Langmuir constants to calculate the theoretical monolayer capacity.

On the other hand, Freundlich isotherm refers to ibuprofen adsorption through nonspecific interactions (different bonding energies) between the solute and the support on the one hand, and possibly by stacking of solutes on the adsorbent surface.

$$
\text { Ln qe }=\ln K_{f}+\frac{1}{n} \ln C e
$$

where $K_{f}(\mathrm{~L} / \mathrm{g})$ is the Freundlich constant and $\frac{1}{n}$ is the relative adsorption capacity characteristic [40].

\subsubsection{Ibuprofen Kinetic of Release}

IBU-L kinetic release was assessed in batch. Dressing disk samples were placed in a 24-well plate $\left(\right.$ CytoOne $^{\circledR}$ ) containing $2 \mathrm{~mL}$ of PBS pH 7.4 as a release medium. The plate was then stirred $(80 \mathrm{rpm})$ at $37^{\circ} \mathrm{C}$. Aliquots were prepared at different time intervals (30 $\mathrm{min}, 2$, 4, 6, 24, 48 and $72 \mathrm{~h}$ ) and then analyzed by HPLC-UV/Vis method previously described. The withdrawn medium was replaced by an equal volume of fresh PBS solution.

\subsection{Biological Evaluation}

Biological tests were performed following the International and European standards (ISO 10993-5/EN 30993-5) with human lung embryonic epithelial cells (L132, ATCC-CCL5). 
The L132 cells were cultured in the modified minimum essential medium (MEM, Gibco ${ }^{\circledR}$, Life Technology, Carlsbad, CA, USA) supplemented with $10 \% v / v$ of fetal calf serum $\left(\right.$ Gibco $^{\circledR}$, Life Technology), streptomycin $(0.1 \mathrm{~g} / \mathrm{L})$, and penicillin $(100 \mathrm{IU} / \mathrm{mL})$, at $37^{\circ} \mathrm{C}$ in a $\mathrm{CO}_{2}$ incubator (CB 150/APT line/Binder, LabExchange, Paris, France) with 5\% CO2/95\% atmosphere and $100 \%$ relative humidity.

Dressing sample $\left(6 \mathrm{~cm}^{2}\right)$ were placed in $1 \mathrm{~mL}$ of culture medium (MEM) for $24 \mathrm{~h}$ at $37^{\circ} \mathrm{C}$ under agitation at $80 \mathrm{rpm}$ (Innova40, New Brunswick Scientific, France). In parallel, $4.0 \times 10^{3}$ L132 cells per well were seeded in a 96-well tissue culture plate containing $100 \mu \mathrm{L}$ of MEM per well. After $24 \mathrm{~h}$, the extraction medium was collected and sterile filtered $\left(0.2 \mu \mathrm{m}\right.$, PB Acrodisc ${ }^{\circledR}$; PALL, Saint-Germain-en-Laye, Enfield, CT, USA). The culture medium was removed from the cells and $100 \mu \mathrm{L} /$ well of the filtrated extraction medium or CCM (negative control), i.e., absence of cytotoxicity, were respectively added to the wells. After $24 \mathrm{~h}$ of incubation, the cell viability was measured by the AlamarBlue ${ }^{\circledR}$ assay (ThermoFisher Scientific, Illkirch, France). Briefly, extraction medium was removed from the cells and $200 \mu \mathrm{L} /$ well of a 10\% AlamarBlue ${ }^{\circledR}$ in MEM solution were added to the wells and placed, protected from light, in an incubator for $2 \mathrm{~h}$. Then, $150 \mu \mathrm{L}$ of the AlamarBlue ${ }^{\circledR}$ solution were recovered from each well and transferred into a flat bottom 96-well plate. Fluorescence was measured at an excitation wavelength of $530 \mathrm{~nm}$ and an emission wavelength of $590 \mathrm{~nm}$, on a microplate fluorometer (TwinkleTMLB 970; Berthold Technologies GmbH \& Co, Wildbad, Germany). The fluorescence readings were normalized relative to that of the negative controls. The experiments were performed in triplicate.

\subsection{Microbiological Evaluation}

The microbiological evaluation of dressings was determined against Staphylococcus aureus (strain CIP224) and Escherichia coli (strain K12). Bacterial culture was realized by inoculating a Mueller-Hinton Agar (MHA) slant incubated for one day at $37^{\circ} \mathrm{C}$. A volume of $10 \mathrm{~mL}$ of Ringer's cysteinated medium was added to the bacteria culture, then bacteria were removed them from the slant. The bacterial suspension contains about $1 \times 10^{9} \mathrm{CFU}$ (colony forming unit) $/ \mathrm{mL}$ approximately.

\subsubsection{Kirby-Bauer Test}

Kirby-Bauer tests were performed to evaluate the influence of ibuprofen lysinate on the antibacterial activity of silver. Disk samples (Ø $11 \mathrm{~mm}$ ) were dipped in $1 \mathrm{~mL}$ of PBS, pH 7.4 and were then stirring $(80 \mathrm{rpm})$ at $37^{\circ} \mathrm{C}$ for $72 \mathrm{~h}$ with a daily change of PBS solution. $18 \mathrm{~mL}$ of Mueller-Hinton agar (MHA) were poured in Petri dishes $(\varnothing 9 \mathrm{~cm})$. Then, $0.1 \mathrm{~mL}$ of $E$. coli at $1 \times 10^{4} \mathrm{CFU} / \mathrm{mL}$ was seeded on the agar. Then, at each interval of evaluation, the textiles samples were deposited onto Mueller Hinton agar plates. After $24 \mathrm{~h}$ of incubation at $37^{\circ} \mathrm{C}$, the diameter of the inhibition zone is measured and plotted as a function of contact time in PBS.

\subsubsection{Kill-Time Test}

Kill-time test was performed to evaluate the kinetics of the bacterial reduction to determine the antibacterial activity of dressings [11]. Disks samples $(\varnothing 11 \mathrm{~mm})$ were placed into 24 well plates $\left(\mathrm{CytoOne}^{\circledR}\right)$. Then, $200 \mu \mathrm{L}$ of a bacterial suspension $\left(1 \times 10^{7} \mathrm{CFU} / \mathrm{mL}\right)$ were placed on the textile samples and the plate was incubated at $37^{\circ} \mathrm{C}$. At each interval examination $(0.5,2,4,6$ and $24 \mathrm{~h})$ disk samples were removed from the well and placed in $2 \mathrm{~mL}$ of PBS, pH 7.4, treated in an ultrasonic bath for $1 \mathrm{~min}$ and vortexed for $30 \mathrm{~s}$ to collect the living bacteria. Successive 1/10 dilutions in cysteinated Ringer solution (CR) were made up to $10^{-4}$ from the recovered bacterial suspension and $0.1 \mathrm{~mL}$ of each dilution was seeded onto Mueller-Hinton agar (MHA). The plates were then incubated for $24 \mathrm{~h}$ at $37^{\circ} \mathrm{C}$. The number of viable bacteria was counted and expressed in Log CFU mL ${ }^{-1}$. 


\section{Results}

\subsection{Study of the Interactions between IBU and PCD in Solution}

Loftsson et al. have abundantly reported the use of pristine cyclodextrins and cyclodextrins derivates as solubility enhancers of many pharmaceutic molecules in water [36,55]. Crosslinked cyclodextrins polymers also present excellent performances as drug carriers. Trotta et al. have reported the good performances and the versatility of their nanosponges [56]. Besides, our team has reported the same properties of our poly(cyclodextrin citrate) toward triclosan [39], ciprofloxacin [40], simvastatin [46], ethoxzolamide [57].

Ibuprofen is a poorly water-soluble drug and its molecular structure makes it a good candidate to form inclusion complexes with cyclodextrins. Figure 2 shows the phase solubility diagram at $\mathrm{pH}=2$ of IBU in presence of increasing concentrations of $\beta C D$ in its native form and in its polymerized form, (PCD), considering PCD contains $50 \%$ in weight of $\beta C D$. According Higuchi and Connors [47], IBU solubility presents an $A_{L}$ profile in presence of PCD, indicating a linear increase of drug solubility with PCD concentration.

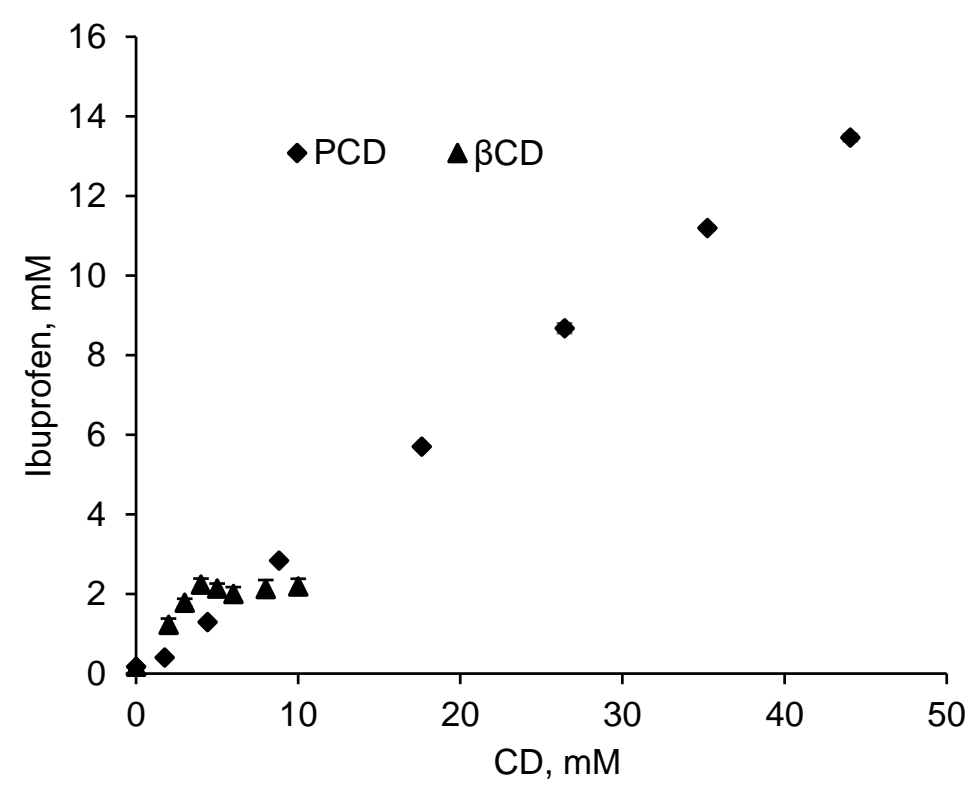

Figure 2. Solubility diagram of IBU with increasing concentrations of pristine $\beta C D$ and polymerized $\beta C D(P C D)$ in a $\mathrm{pH}=2$ buffer solution $(\mathrm{KCl} 0.2 \mathrm{M}$ and $\mathrm{HCl} 0.1 \mathrm{M})$ at room temperature after $24 \mathrm{~h}$ of stirring $(210 \mathrm{rpm})$.

On the other hand, in presence of $\beta C D$, IBU solubility reported a $B_{S}$ profile which refers to an increase of drug solubility up to $[\beta C D]=5 \mathrm{mmol} / \mathrm{L}$, followed by a plateau showing a limited solubility levelling off at $2 \mathrm{mM}$. This plateau is due to the low intrinsic solubility of $\beta C D\left(16 \mathrm{mmol} / \mathrm{L}\right.$ in water at $\left.20{ }^{\circ} \mathrm{C}\right)$ that involves the precipitation of the inclusion complex $\beta C D-I B U[36,55]$. This result is in accordance with Pereva et al., [58] and di Cagno et al., [59] who reported the same $B_{S}$ solubility profile of ibuprofen in presence of $\beta C D$.

The $A_{L}$ profile in the whole range of concentration studied is due to the substantially higher solubility of PCD which is far below its limit of solubility $(1 \mathrm{~g} / \mathrm{mL}$, corresponding to $0.44 \mathrm{~mol} / \mathrm{L}$ of $\beta C D$ units in the solution) compared to pristine $\beta C D$. Figure 1 displays in presence of PCD corresponding to a concentration of up to $44 \mathrm{mmol} / \mathrm{L}$ in $\beta C D$ units, IBU apparent solubility increases up to $13.0 \mathrm{mmol} / \mathrm{L}(2680 \mathrm{mg} / \mathrm{L})$ which corresponds to a solubilization factor of 77. Besides, the limit solubility of IBU is $2.0 \mathrm{mmol} / \mathrm{L}(412 \mathrm{mg} / \mathrm{L})$ in presence of pristine $\beta C D$ from $5 \mathrm{mmol} / \mathrm{L}$, corresponding to a solubilization factor of 12 (Table 1). 
Table 1. Association constant $\left(K_{f}\right)$, complexation efficiency $(\mathrm{CE})$ and slope values of $\beta C D$ and PCD.

\begin{tabular}{ccccc}
\hline & $K_{f}\left(\mathbf{m M}^{-1}\right)$ & CE & Slope & Solubilization Factor \\
\hline$\beta C D$ & 6200 & 1.08 & 0.52062 & $12^{\mathrm{b}}$ \\
$\mathrm{PCD}$ & 2600 & 0.45 & 0.31308 & $77^{\mathrm{a}}$ \\
\hline
\end{tabular}

Solubilization factor for $\beta C D$ cavities concentration ${ }^{a} 44 \mathrm{mmol} / \mathrm{L},{ }^{b} 5 \mathrm{mmol} / \mathrm{L}$.

Association constant $\left(K_{f}\right)$ and complexation efficiency (CE) values calculated from the solubility diagram according to Equations (3) and (4) are presented in Table 1. These data are both calculated from the slopes of the linear increasing portions of the solubility diagrams, i.e., at concentration below $5 \mathrm{mmol} / \mathrm{L}$ for $\beta C D$ and for the whole concentration range for PCD. The slopes values are 0.52062 and 0.31308 for $\beta C D$ and PCD respectively. Based on these values, calculated $K_{f}$ value are $6200 \mathrm{~L} / \mathrm{mmol}$ and $2600 \mathrm{~L} / \mathrm{mmol}$, and complexation efficiencies are 1.08 and 0.45 , respectively. Such feature can be explained by the higher accessibility of CD cavities in pristine $\beta C D$ compared to PCD. In the latter case, PCD has a hyperbranched structure forming globular objects of $50 \mathrm{~nm}$ diameter [60] where CD cavities situated inside the nano objects present lower accessibility compared to those present at their surface.

However, due to the $B_{s}$ profile the apparent solubility of IBU levels off at $2.0 \mathrm{mmol} / \mathrm{L}$ from $5 \mathrm{mmol} / \mathrm{L}$ in $\beta C D$, while the $A_{L}$ profile displayed a IBU concentration increasing up to $13.5 \mathrm{mmol} / \mathrm{L}$ for a concentration of $44 \mathrm{mmol} / \mathrm{L}$ in the polymerized form of $\beta C D$. So, the inconvenience of the lower accessibility of CD cavities in the polymerized form compared to the polymerized form is largely compensated by the very high solubility of PCD. Finally, the slope values of obtained curves are 0.52062 and 0.31308 for $\beta C D$ and PCD respectively. These values are lower than 1 indicating an inclusion complex of type 1:1 [61].

\subsection{NMR study of the PCD/IBU complex}

A proton NMR study was performed in order to evidence the complexation between IBU and PCD. Figure 3 displays the spectrum of poly(cyclodextrin citrate) (PCD), ibuprofen (IBU) and PCD/IBU complex. The ${ }^{1} \mathrm{H}$ NMR spectrum of PCD shows the signal of the glucopyranose units of cyclodextrins, $\mathrm{H}_{1}$ (5 ppm); $\mathrm{H}_{3}, \mathrm{H}_{5}, \mathrm{H}_{6}, \mathrm{H}_{4}$ and $\mathrm{H}_{2}$ are located between 3.58 and $3.99 \mathrm{ppm}$. The methylene groups of the crosslinking agent (CTR) appear between 2.76 and $2.96 \mathrm{ppm}$. In Figure 3B the signal of aromatic protons of IBU appear as two doublets corresponding to $\mathrm{H}_{9}$ and $\mathrm{H}_{5}$ at 7.23 and $7.21 \mathrm{ppm}$, and $\mathrm{H}_{6}$ and $\mathrm{H}_{8}$ present at 7.15 and 7.18 ppm respectively. The spectrum of PCD/IBU complex displays a downfield shift of IBU aromatic proton signals at $7.20 \mathrm{ppm}$ and $7.05 \mathrm{ppm}$. Besides, the signals of the internal protons of $\mathrm{CD}$ units $\mathrm{H}_{5}$ and $\mathrm{H}_{3}$ display upfield shifts as observed in Figure $3 \mathrm{C}$. These spectral changes suggest a complexation of the aromatic group of IBU inside the cavities of CD units of PCD.

The PCD/IBU complex was analyzed more in depth by $1 \mathrm{H}$ NMR applying a NOESY sequence (Rotating Frame Overhauser Effect Spectroscopy). As observed in Figure 4, the 2D-NOESY NMR spectrum displays the correlation between $\mathrm{H}_{3}$ and $\mathrm{H}_{5}$ protons of cyclodextrin cavities with aromatic protons of IBU, confirming the inclusion of IBU into $\beta C D$ s cavities of PCD. 


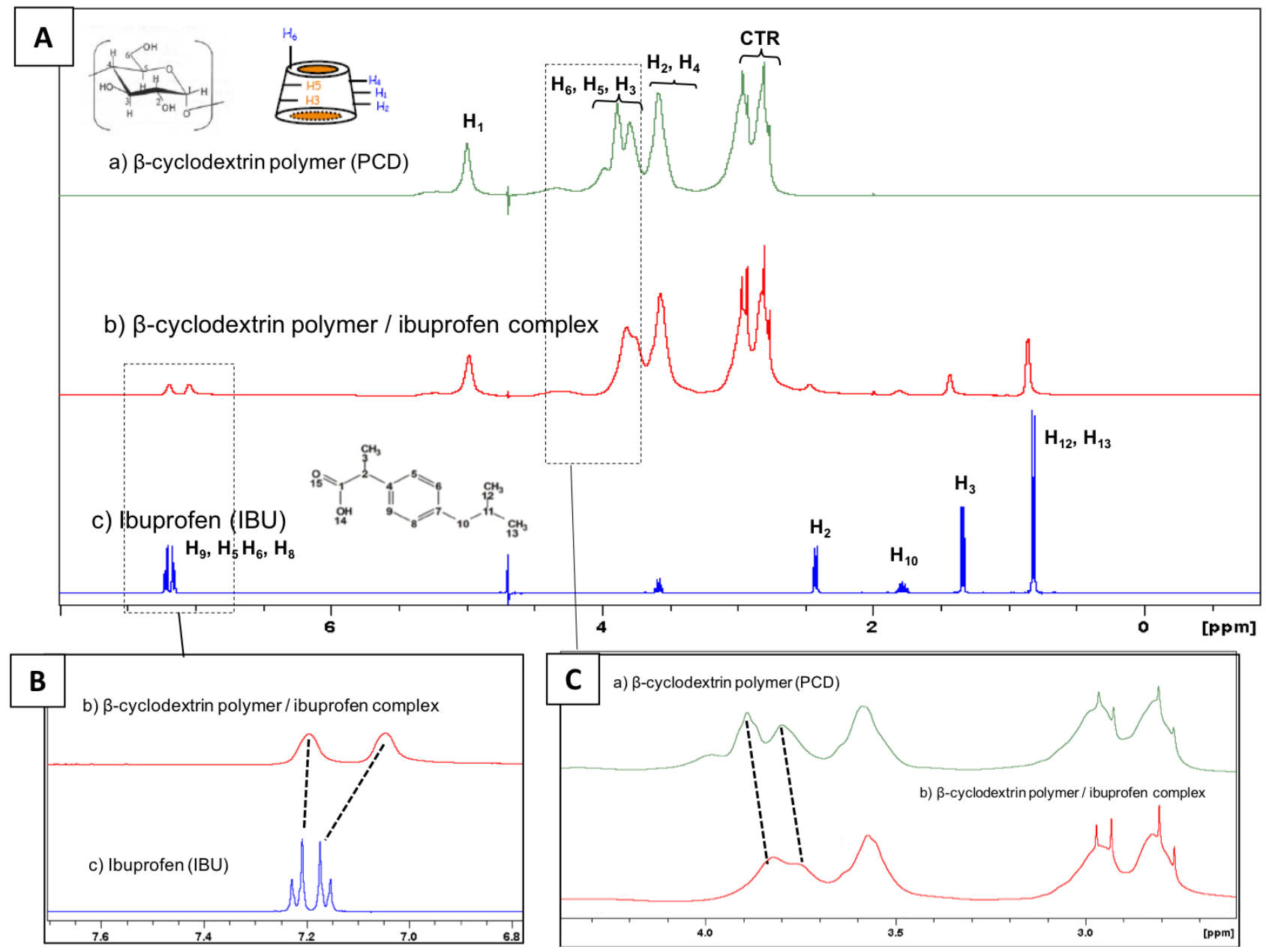

Figure 3. (A) Full scale ${ }^{1} \mathrm{H}$ NMR in $\mathrm{D}_{2} \mathrm{O}$ of (a) $\beta$-cyclodextrin polymer (PCD); (b) $\beta$-cyclodextrin polymer/ibuprofen complex and (c) ibuprofen (IBU). (B) Magnifications focusing on the signals of aromatic protons of IBU and (C) on the signals of PCD protons.

\subsection{Ibuprofen Lysinate Adsorption and Kinetic of Release}

\subsubsection{Adsorption Isotherms}

Adsorption isotherm analyses were performed to investigate the adsorption mechanisms of ibuprofen lysinate on PET-CD-Ag-PEM dressings. Adsorption phenomenon is characterized by the equilibrium between dissolved and adsorbed forms of the solute in function of the initial concentration of the solution, that informs on the interactions mechanisms between the sorbent and the species in the solution. In this section, ibuprofen lysinate was preferred to ibuprofen acidic form due to the very low intrinsic solubility of ibuprofen discussed above, which is a limiting factor for the loading of the dressings. 


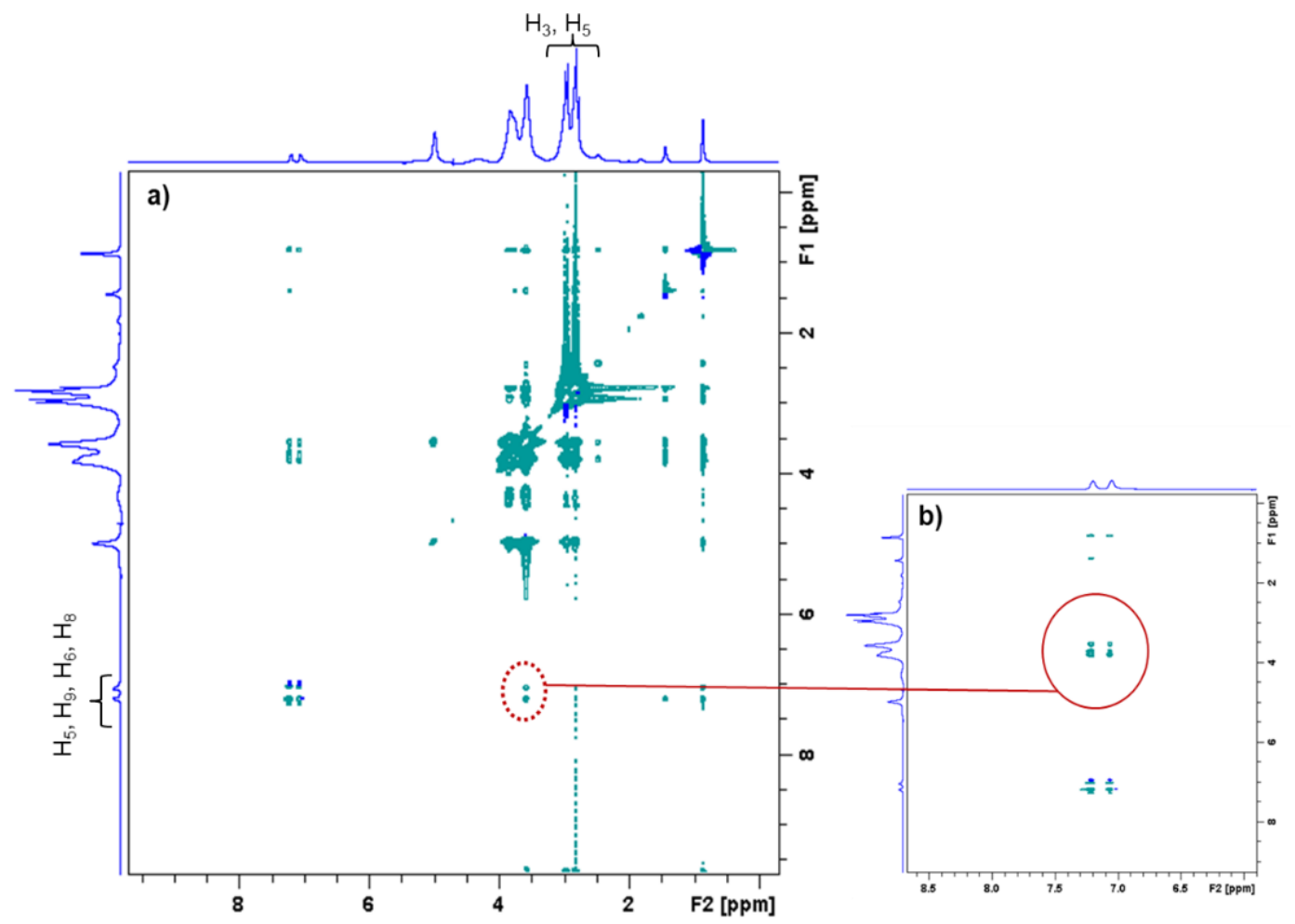

Figure 4. (a) 2D-NOESY NMR spectrum of PCD and IBU. (b) Enlargement of 2D-NOESY NMR spectrum. The red circle indicates the correlation mark corresponding the inclusion of IBU into the $\beta C D$ cavities of PCD.

Figure 5a displays the amount of loaded ibuprofen lysinate (IBU-L) (qe) onto PETCD-Ag-PEM dressing as a function of IBU-L concentration in the impregnation bath at the equilibrium $(\mathrm{Ce}, \mathrm{mg} / \mathrm{L})$. The amount of IBU-L adsorbed onto dressing increases as a function of IBU-L concentration used for the impregnation. However, the curve presents two parts. First, an increase (around 30 times higher) in the amount of adsorbed IBU-L was observed when the concentration of the impregnating solution increases from $0.1 \mathrm{~g} / \mathrm{L}$ to $1 \mathrm{~g} / \mathrm{L}$. The concentration of IBU-L adsorbed increased from $3.26 \pm 0.21 \mu \mathrm{g} / \mathrm{cm}^{2}$ to $93 \pm 4 \mu \mathrm{g} / \mathrm{cm}^{2}$ respectively. Secondly, when the concentration of impregnation increased from $1 \mathrm{~g} / \mathrm{L}$ to $10 \mathrm{~g} / \mathrm{L}$, the amount of IBU-L adsorbed was only 1.7 times higher, presenting adsorbed concentrations of $93 \pm 4 \mu \mathrm{g} / \mathrm{cm}^{2}$ and $163 \pm 33 \mu \mathrm{g} / \mathrm{cm}^{2}$ respectively.

In the case of ibuprofen acidic form, (data not presented), the same trend as IBU-L was observed. However, the curve was interrupted at $990 \mathrm{mg} / \mathrm{L}(\mathrm{Ce})$ of IBU-L, because of the solubility limitation in water of this drug in its acidic form.

As shown in Figure $5 b$, linearization obtained from isotherms data reported an adsorption model similar to the Langmuir model. As a matter of fact, the linearization of $\mathrm{Ce} / q e$ as a function of $C e$, represents a straight line $\left(R^{2}=0.9898\right)$ and the Langmuir constants were $K_{L}=163, q m=4.47 \mu \mathrm{g} / \mathrm{cm}^{2}$ and $\alpha L=36.48$. In contrast, Freundlich model (Figure $5 \mathrm{c}$ ) showed a straight line $\left(\mathrm{R}^{2}=0.9477\right)$ lower than the one showed in Langmuir model. Therefore, IBU-L adsorption onto PET-CD-Ag-PEM dressings follows the Langmuir model. This means that drug adsorption is carried out in a monolayer by interaction between one sorption site of the support and one molecule of IBU-L.

Raw data of sorption isotherms $(q e=f(C e)$ were not possible to exploit accordingly with both Langmuir nor Freundlich models due to the low limit of solubility $(<1 \mathrm{~g} / \mathrm{L})$ of ibuprofen acidic form. Nevertheless, adsorbed ibuprofen on treated textiles samples loaded by dipping in saturated drug solution reached $95 \mu \mathrm{g} / \mathrm{cm}^{2}$ at equilibrium. Therefore, dressings were loaded with ibuprofen lysinate (IBU-L) in the rest of this work. 


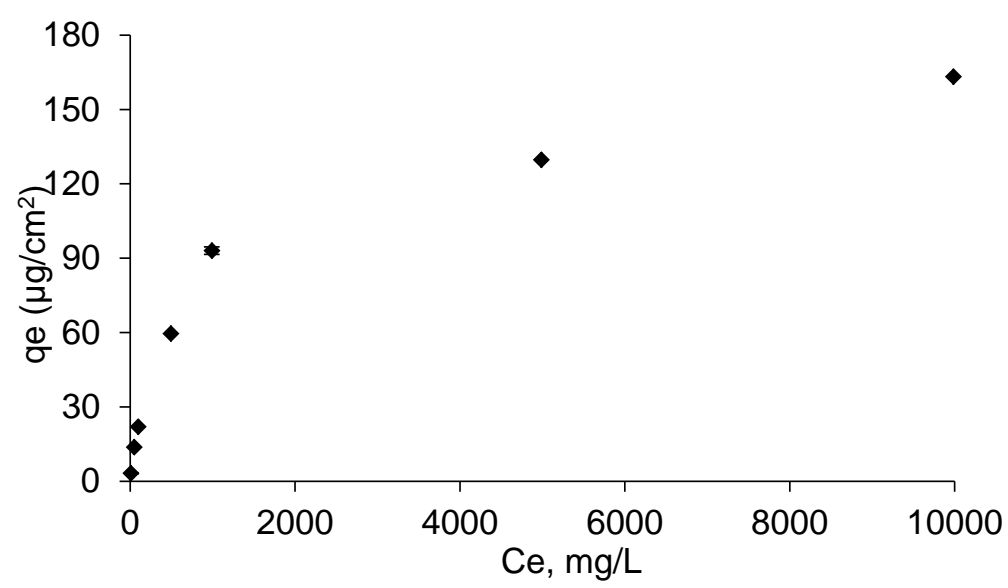

(a)

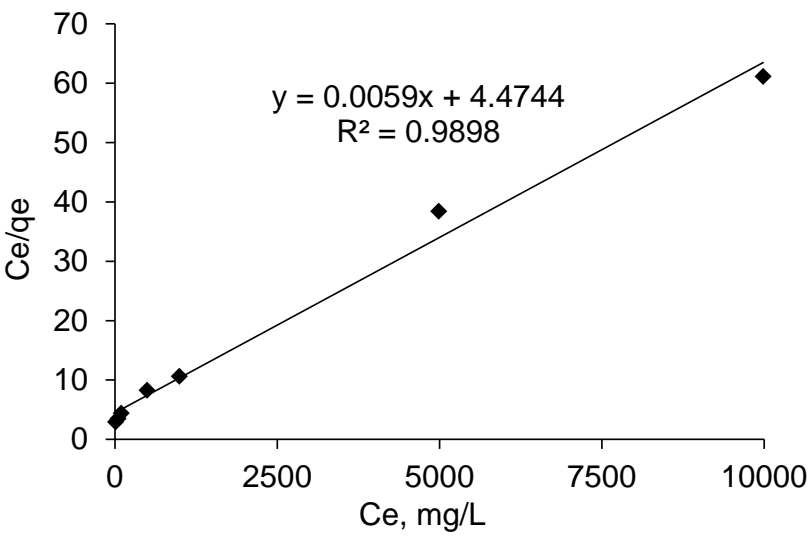

(b)

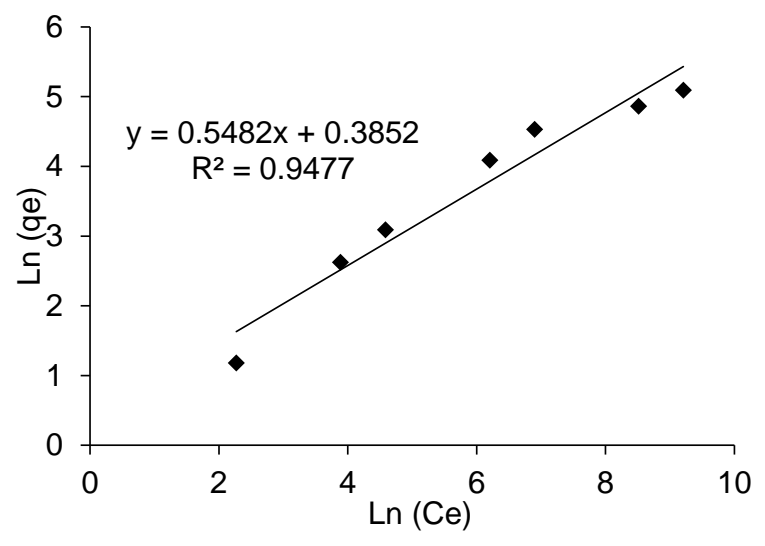

(c)

Figure 5. (a) Adsorption isotherm of IBU-L onto PET-CD-Ag-PEM dressings after $24 \mathrm{~h}$ of impregnation at $240 \mathrm{rpm}$ at room temperature. (b) the Langmuir isotherm of adsorption, and (c) Freundlich isotherm of adsorption.

\subsubsection{Ibuprofen Loading on Dressing Samples}

Dressings samples corresponding to PET-CD, PET-CD-PEM and PET-Ag-PEM were impregnated in IBU-L solution at 3 different concentrations: 1,5 and $10 \mathrm{~g} / \mathrm{L}$, for $24 \mathrm{~h}$ at room temperature. This assay was carried out to (1) determine the concentration of impregnation bath to obtain an appropriate dose of IBU-L to relieve pain (in comparison to commercial dressing Biatain ${ }^{\circledR} \mathrm{Ibu}, 500 \mu \mathrm{g} / \mathrm{cm}^{2}$ ). (2) Evaluate the performance of the PEM system on drug loading, specifically in the presence of silver.

Figure 6 shows the total amount of IBU-L on dressing samples. This result reports a rise of IBU-L adsorption as the concentration of impregnation bath increases, this trend has been observed in the case of isotherms previously reported. PET-CD showed a low charge of IBU-L compared to PET-CD-PEM dressing. The amount of IBU-L adsorbed onto PET-CD was 51,65 and $105 \mu \mathrm{g} / \mathrm{cm}^{2}$ for a concentration of impregnation of 1,5 and $10 \mathrm{~g} / \mathrm{L}$ respectively. At the same time, the amount of IBU-L adsorbed onto PET-CD-PEM was more than double: 109, 173 and $214 \mu \mathrm{g} / \mathrm{cm}^{2}$, respectively. The presence of PCD in the multilayer coating makes possible the ibuprofen lysinate adsorption onto functionalized supports. On the other hand, virgin PET textile was also impregnated in IBU-L solutions with the same concentrations, but the adsorbed amount was not detectable. This situation evidences the importance of PCD for drug loading on dressings supports. 


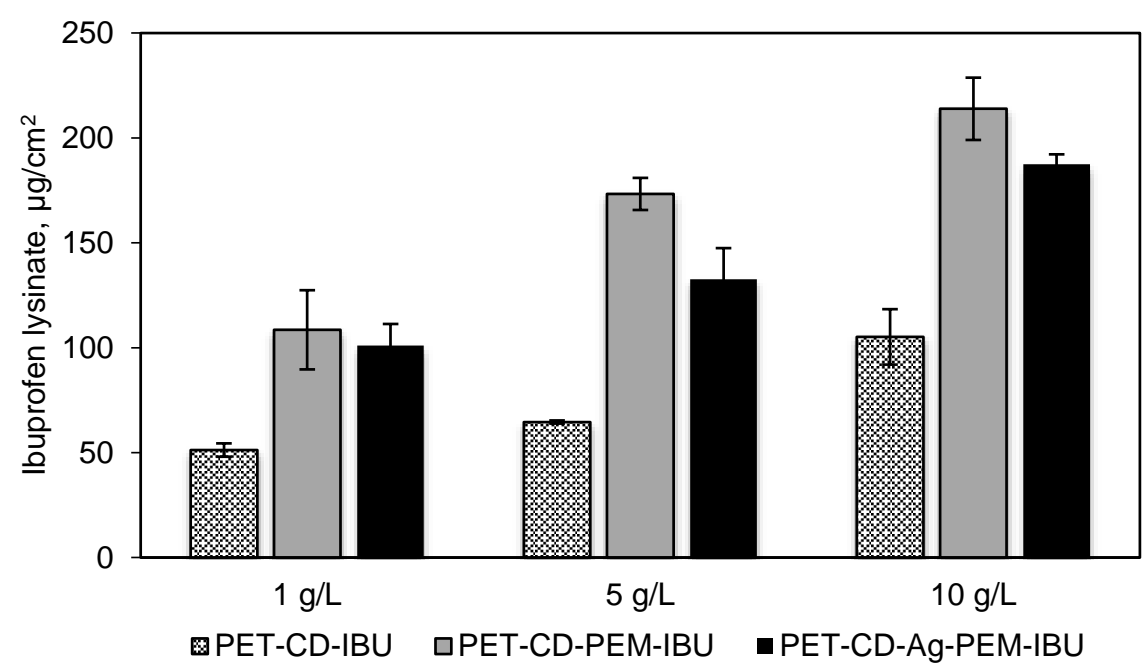

Figure 6. IBU-L adsorbed onto PET-CD, PET-CD-PEM and PET-CD-Ag-PEM dressings. Samples were impregnated in 3 concentrations of IBU-L solutions $(1,5$ and $10 \mathrm{~g} / \mathrm{L})$ overnight. The assay was carried out by HPLC-UV.

In the case of PET-CD-Ag-PEM-IBU dressings, the results showed a lower amount of IBU-L adsorbed than non-silver loaded dressings, regardless the concentration of impregnation used. This phenomenon is probably due to the fact that silver nanoparticles, interact with amine and carboxylic functions of the thermo-fixed and self-assembled layers of the PEM system, affecting thus the adsorption capacity of the PEM coating.

These results reported that the IBU-L concentration of $10 \mathrm{~g} / \mathrm{L}$ allowed a maximum drug loading (in the range of $200 \mu \mathrm{g} / \mathrm{cm}^{2}$ ) on our dressings without reaching the dosage present in commercial dressing (Biatain ${ }^{\circledR} \mathrm{Ibu}, 500 \mu \mathrm{g} / \mathrm{cm}^{2}$ ). This concentration was selected to prepare the final dressing named hereafter PET-CD-Ag-PEM-IBU.

\subsubsection{Ibuprofen Kinetics Release}

Ibuprofen lysinate kinetics release was performed in PBS pH 7.4 and evaluated under static conditions, in order to evaluate the performance of the PEM as drug release system. Figure 7 displays the amount of IBU-L released $\left(\mu \mathrm{g} / \mathrm{cm}^{2}\right)$ as a function of time on different dressings. PET-CD-IBU samples release, after $30 \mathrm{~min}$, around of $80 \pm 8 \mu \mathrm{g} / \mathrm{cm}^{2}$, representing a rate of $76 \%$ in comparison to the initial dosage, showing a burst effect. Then, the totality of the IBU-L loaded was released in $1 \mathrm{~h}$. These performances reveal that the application of a monolayer (pre-treatment of PET step, layer \# 1) is not sufficient to obtain a prolonged release of the drug.

In contrast, samples presenting the PEM coating showed a prolonged release profile. As a matter of fact, PET-CD-PEM-IBU (silver-free dressing) achieves a concentration of $116 \pm 5 \mu \mathrm{g} / \mathrm{cm}^{2}$, after $30 \mathrm{~min}$, representing a rate of $54 \%$. Then, the rest of IBU-L loaded $\left(200 \pm 15 \mu \mathrm{g} / \mathrm{cm}^{2}\right)$ was released in $6 \mathrm{~h}$. Moreover, the same trend was observed for PETCD-Ag-PEM-IBU dressing. In fact, the amount of IBU-L released, after $30 \mathrm{~min}$, reached up to $104.0 \pm 1.5 \mu \mathrm{g} / \mathrm{cm}^{2}$, representing a rate of $56 \%$. Finally, the total IBU-L loaded $\left(187 \pm 5 \mu \mathrm{g} / \mathrm{cm}^{2}\right)$ was also released after $6 \mathrm{~h}$. 


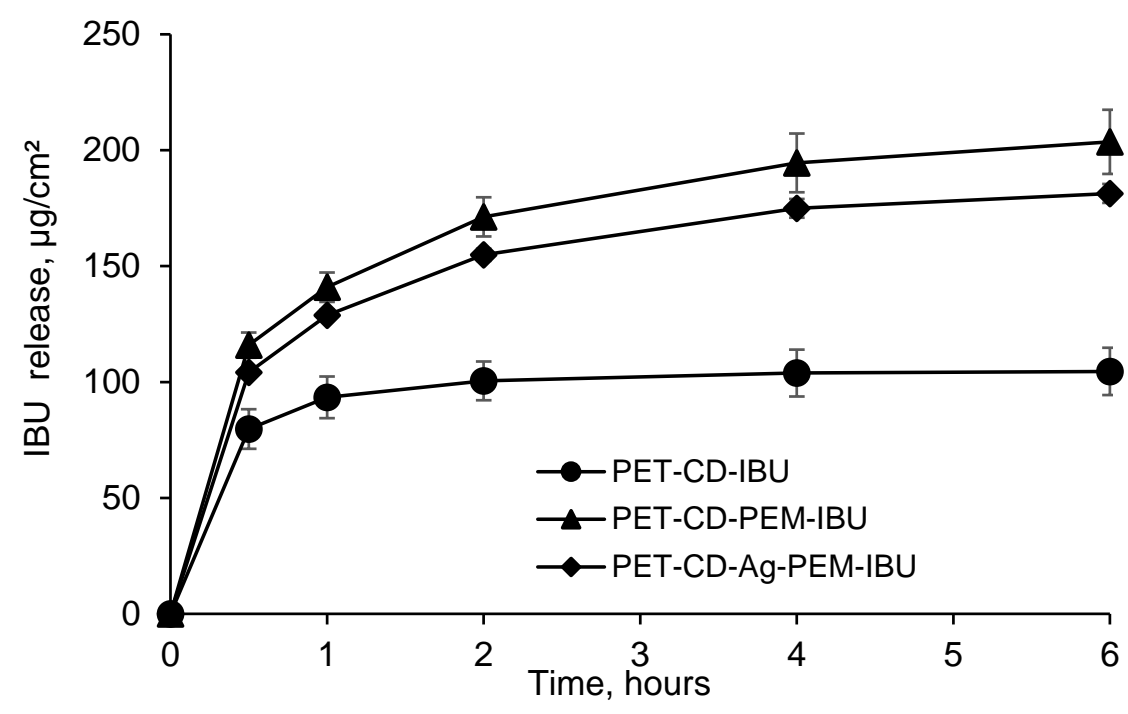

Figure 7. Kinetics release of ibuprofen lysinate (IBU-L) in batch, expressed in $\mu \mathrm{g} / \mathrm{cm}^{2}$ (PBS pH 7.4, $37^{\circ} \mathrm{C}, 80 \mathrm{rpm}$ ) from PET-CD-IBU, PET-CD-PEM-IBU and PET-CD-Ag-PEM-IBU dressings.

The presence of the PEM coating onto textile supports allows a slower release of IBU-L compared to textiles presenting only a monolayer (PET-CD-IBU). Indeed, this is in agreement with our previous works where we observed a prolonged release of silver, chlorhexidine and methylene blue from textile supports coated with similar multilayer assemblies $[10,23,49]$. These studies displayed that not only the release kinetic was dependent from the number of layers in the layer-by-layer coatings, but was also dependent of a final post-treatment of the modified substrates by thermal or chemical crosslinking of the multi-layered coating.

IBU-L release tests were performed in batch, these results reported a release time over $6 \mathrm{~h}$ which can appear very fast. However, the used conditions in this work were different from those of the dressing applied to a wound presenting a very limited exudate flow. Therefore, closer models must be studied. For example, Steffansen and Herping have developed an in vitro release model for the commercial dressing Biatain ${ }^{\circledR}$ Ibu using Franz diffusion cells [62]. The study concludes that the complete release of ibuprofen dose $(500 \mu \mathrm{g})$ occurs in 7 days with a zero-order kinetics release. The results obtained from this in vitro model were correlated with the data collected from the in vivo release model for dressings proposed by Jorgensen et al., [18]. Thus, the in vitro release model proposed by Steffansen and Herping could be applied to evaluate the drug release profile of IBU-L on dressings developed in this work.

\subsection{Biological Evaluation}

Cell viability was determined on dressing sample by the extraction method, after $24 \mathrm{~h}$ of incubation in culture medium (MEM). Figure 8 shows the viability rates of the L132 cells obtained on sample corresponding to each stage of the development of the dressing. The PET exhibited a viability rate of $87 \%$, which shows an absence of cytotoxicity compared to the negative control. The cell viability obtained PET-CD is 79\%. PET-CD showed a lower rate of cell viability than PET, which can be explained by the density of residual $\mathrm{COOH}$ functions present in textiles provided by poly(cyclodextrin citrate). 


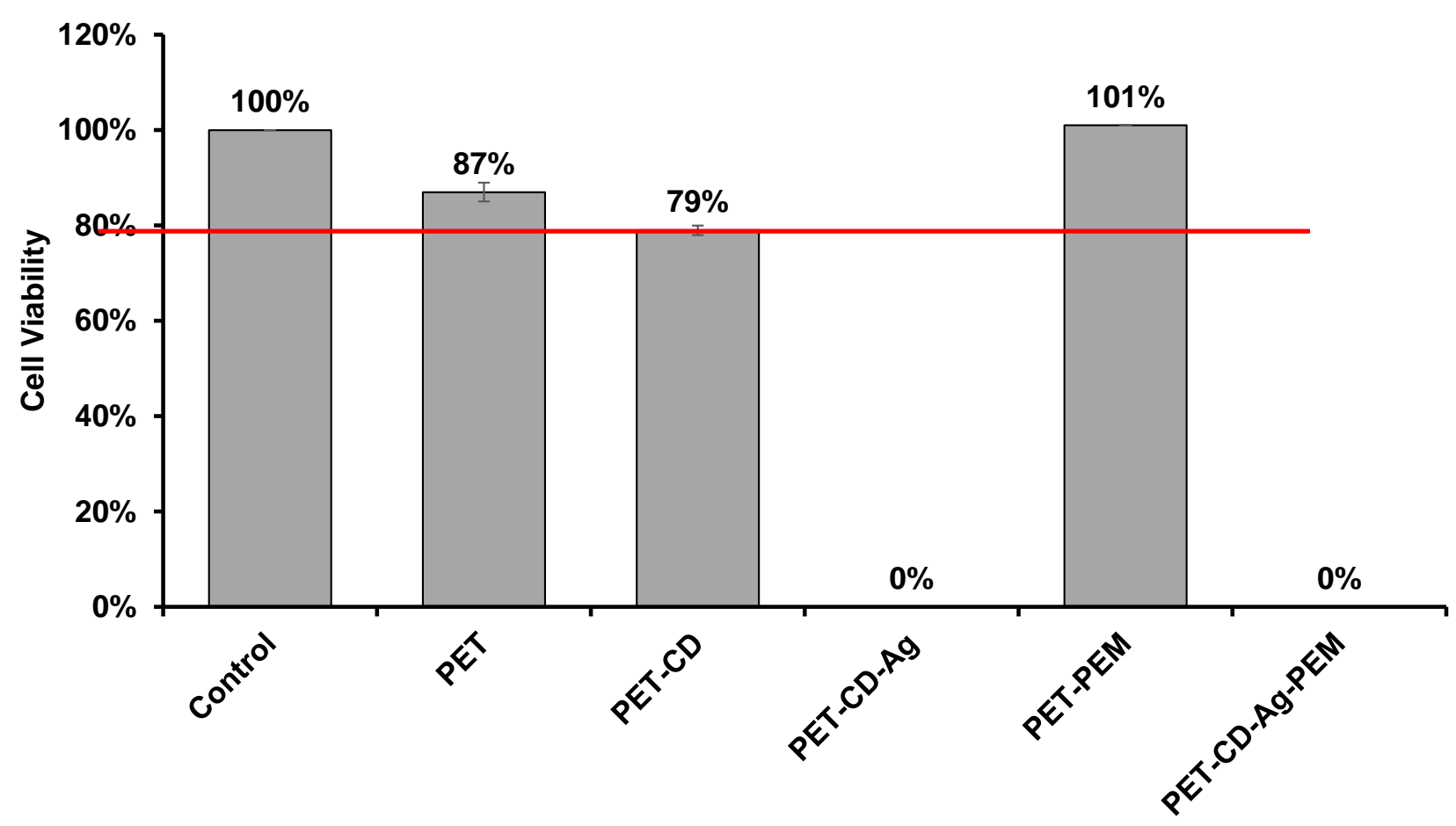

Figure 8. Cell viability of L132 line cell evaluated on different textiles by the extraction method after $24 \mathrm{~h}$ of incubation $(\mathrm{n}=8)$.

On the other hand, the PEM system applied to the samples (PET-CD-PEM) showed optimal cell viability of $101 \%$. It is worth mentioning that the heat treatment $\left(140{ }^{\circ} \mathrm{C}\right.$, $105 \mathrm{~min}$ ) applied to the PEM system contributed to such good cell viability. As a matter of fact, this treatment provoked the crosslinking of the multilayer assemblies [10] and thus limited the diffusion of PCD in the culture medium preventing the acidification of the cell culture medium (MEM medium enriched with 10\% SVF (MEM + SVF)) [63].

However, textiles loaded with silver show cytotoxicity ( $0 \%$ cell viability). This phenomenon is due to the diffusion of part of the silver in the MEM + SVF medium, to reach toxic concentrations. Similar results are obtained with a commercial dressing (UrgoTUL ${ }^{\circledR}$ $\mathrm{Ag}$ ) under the same analytical conditions. However, with different media (MEM + SVF, MEM and PBS), the amount of silver extracted was 3 to 6 times greater in the commercial dressing than in PET-CD-Ag-PEM-IBU depending on the extraction medium (PBS, MEM, MEM + SVF) (Supplementary Figure S1). So, this test displayed that the cytotoxicity of our dressing is potentially less toxic than the commercial one as it liberates silver in a lesser extent.

\subsection{Microbiological Evaluation}

Microbiological evaluation was performed in order to evaluate the influence of IBU-L on the antibacterial properties of silver. Figure 9 shows the inhibition zone diameters against $E$. coli for freshly prepared samples and samples after immersion in PBS media ( $\mathrm{pH} 7.4$ ) for 24,48 and $72 \mathrm{~h}$ with the aim of simulating the duration of treatment. 


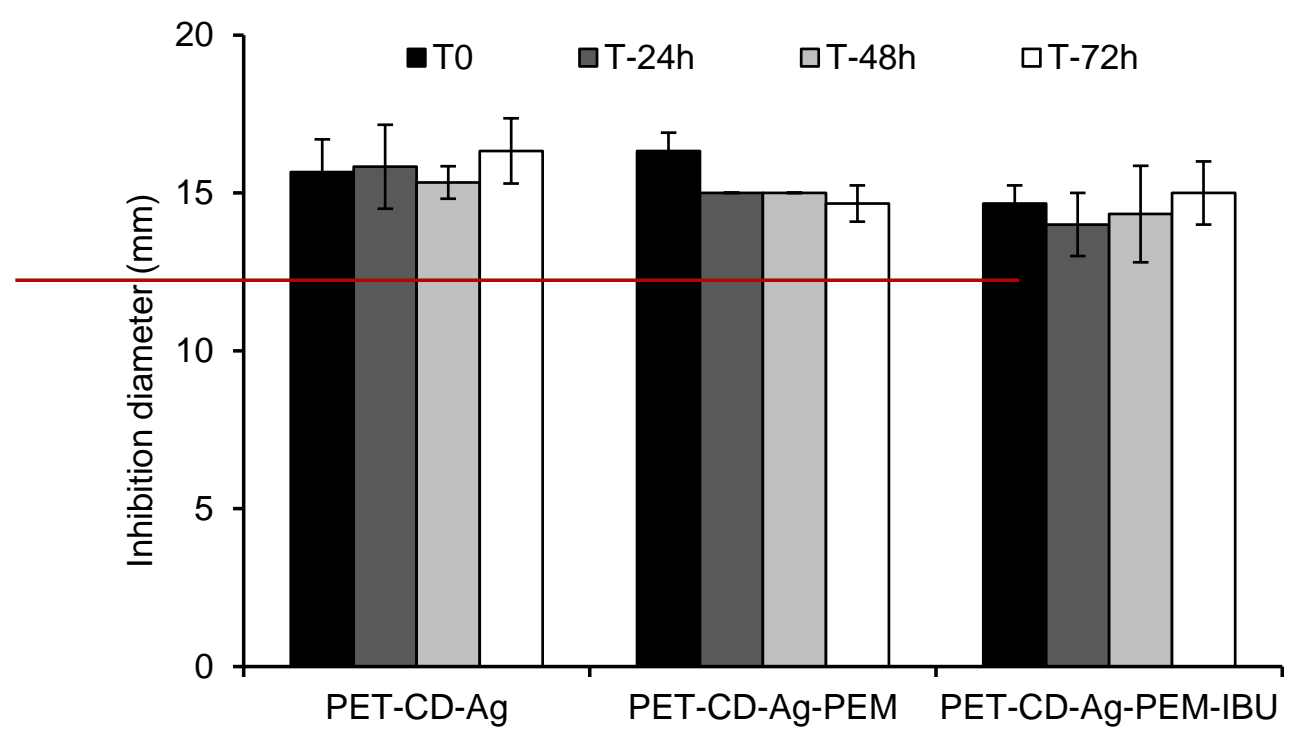

Figure 9. Inhibition diameter in the Kirby-Bauer test against E. coli of dressing samples at $0,24,48$ and $72 \mathrm{~h}$ of immersion in PBS pH 7.4 media $\left(80 \mathrm{rpm}, 37^{\circ} \mathrm{C}\right)$. The red line in the graph indicates the diameter of dressing samples (11 mm) placed onto Muller-Hinton agar.

The inhibition diameter presented for PET-CD-Ag dressing was $16.3 \pm 1 \mathrm{~mm}$, after 3 days. When the PEM system is applied, the diameter of inhibition of PET-CD-Ag-PEM dressing was $16.3 \pm 1 \mathrm{~mm}$ at the beginning of analysis and was reduced to $14.6 \pm 0.6 \mathrm{~mm}$ after 3 days. On the other hand, the dressing containing IBU-L didn't show significant differences except at $\mathrm{T} 0$, probably due to a loss of silver during the impregnation step of dressing in the IBU-L solution overnight. In fact, inhibition diameter at T0 was $14.67 \pm 0.58 \mathrm{~mm}$ against $16.33 \pm 0.58 \mathrm{~mm}$ for the dressing without IBU-L to finally reach an inhibition diameter around of $15 \pm 1 \mathrm{~mm}$ after 3 days, for both kinds of dressings. These results showed that the inhibition diameters are similar between all groups evaluated whatever the analysis time, concluding that IBU-L does not interfere with the silver diffusion through the multilayer assemblies.

Kill Time Test (Bacterial reduction test) was developed to evaluate the antibacterial activity of different dressings and to measure the rate at which dressings inhibit the bacterial proliferation.

Figure 10 displays the bacterial reduction (expressed on $\log \mathrm{CUF} / \mathrm{mL}$ ) of $S$. aureus (Figure 10a) and E. coli (Figure 10b) that were in contact with dressings at different times $(0.5$ to $24 \mathrm{~h})$. In the case of $S$. aureus, the different dressings show a similar bacterial reduction profile $\left(2.95 \log _{10}\right)$ up to $6 \mathrm{~h}$ of evaluation. At $24 \mathrm{~h}$, PET-CD-Ag dressing achieves a bacterial reduction of $6 \log _{10}$ while PET-CD-Ag-PEM dressing reaches up to $5 \log _{10}$. On the other hand, the antibacterial activity of dressing with IBU-L displayed a slightly lower bacterial reduction, $4 \log _{10}$ at $24 \mathrm{~h}$, compared to dressing without IBU-L.

Considering E. coli (Figure 10b), the PET-CD-Ag dressing presented a bacterial reduction of $3 \log _{10}$ at $30 \mathrm{~min}$, following a gradual reduction of bacteria population to finally reach to $4 \log _{10}$ at $24 \mathrm{~h}$. On the other hand, PET-CD-Ag-PEM dressings showed a faster kinetic reduction. In fact, a bacterial reduction of $4 \log _{10}$ after $30 \mathrm{~min}$ was observed. Then, a reduction of $6 \log _{10}$ was reached after $6 \mathrm{~h}$ of evaluation. Nevertheless, after this time, the bacterial population increased to reach $4 \log _{10}$ at $24 \mathrm{~h}$. Dressings containing IBU-L showed a slow kinetic reduction compared to dressings without IBU-L. A progressive reduction of the bacterial population until $6 \mathrm{~h}$ of contact was perceived, reaching a reduction of $5 \log _{10}$. Then, the same trend as PET-CD-Ag-PEM was observed. Finally, the bacterial reduction after $24 \mathrm{~h}$ reached $4 \log _{10}$. 


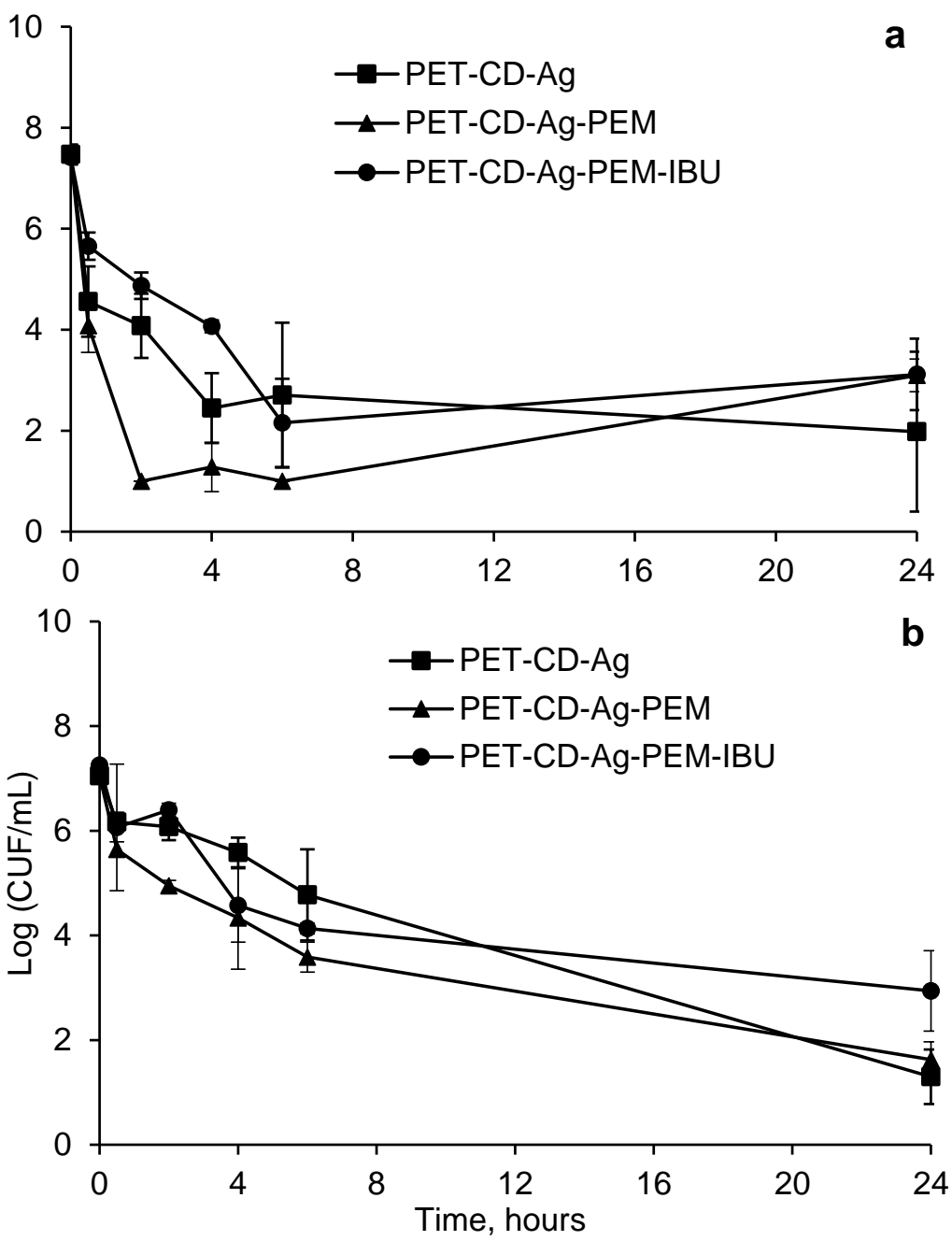

Figure 10. Kinetics bacterial reduction of S. aureus (a) and E. coli (b) in contact with different dressings at different times (0.5 to $24 \mathrm{~h}$ ). Initial bacterial load: $7 \log _{10} \mathrm{CUF} / \mathrm{mL}$.

Figure 10a,b display that PEM coated samples with dual loading of silver and IBU-L present moderate antibacterial activity compared to samples loaded with silver only within the first six hours of the experiment, however both samples a similar antibacterial activity on the two bacterial strains at $24 \mathrm{~h}$ of evaluation.

However, these dressings are still less effective than PET-CD-Ag because they contain the PEM system, preventing the rapid diffusion of silver and thus may reduce toxicity [10].

\section{Conclusions}

In this paper, we reported the development of a wound dressing containing two active ingredients; silver sulfate -as an antibacterial agent-, and ibuprofen-as an antalgic compound-in order to trait infected wounds which chronic pain is associated with. The dressing is based on polyethylene terephthalate (PET) non-woven pre-treated with $\beta C D$ crosslinked with citric acid by pad/dry/cure technique, loaded then by silver sulfate and finally coated by the layer-by-layer technique with a PEM system made up of chitosan (CHT) as a positive polyelectrolyte and poly(cyclodextrin citrate) (PCD) as a negative polyelectrolyte. In a final step, ibuprofen lysinate was loaded onto dressing samples. Solubility diagram and $1 \mathrm{D}$ and $2 \mathrm{D}$ proton NMR spectroscopies demonstrated with the inclusion complexation of IBU in CD cavities of PCD. Adsorption isotherms have shown IBU-L adsorption onto multilayer coated samples following the Langmuir model.

PEM coated samples displayed a sustained release of IBU-L up to $6 \mathrm{~h}$ in comparison with samples not treated layer-by-layer technique (up to $2 \mathrm{~h}$ ). Microbiological evaluation 
revealed that IBU-L loaded multilayer coating keep antibacterial activity against $E$. coli and S. aureus.

In the future, in vivo assays in an infected wounded mice model will be developed in order to evaluate the efficacy of wound dressing in infection eradication. Moreover, the in vitro and in vivo therapeutic activity of IBU-L included in this technical dressing will be evaluated in terms of inflammation (IL, TNF, etc.).

Supplementary Materials: The following are available online at https://www.mdpi.com/article/ $10.3390 /$ antibiotics10070805/s1, Figure S1. Comparison of the amount of silver extracted on the PET-CD-Ag-PEM-IBU (initial silver loading-210 $\mu \mathrm{g} / \mathrm{cm}^{2}$ ) and UrgoTul ${ }^{\circledR}$ - $\mathrm{Ag}$ (initial silver loading $\left.350 \mu \mathrm{g} / \mathrm{cm}^{2}\right)$ dressings after $24 \mathrm{~h}$ stirring $(80 \mathrm{rpm})$ at $37^{\circ} \mathrm{C}$, in different extraction media.

Author Contributions: Conceptualization, B.M. and N.B.; methodology, M.M., N.T., M.J.G.-F., and F.C. validation, M.M., N.T. and M.J.G.-F., investigation A.M.-V., N.T., M.J.G.-F., and F.C.; writingoriginal draft preparation, A.M.-V.; writing-review and editing, B.M., C.N. and N.B.; visualization and supervision, B.M., C.N. and N.B.; project administration and funding acquisition, N.B. All authors have read and agreed to the published version of the manuscript.

Funding: This research was funded by FONDECYT-CONCYTEC (grant number-238-2015-FONDECYT).

Institutional Review Board Statement: Not applicable.

Informed Consent Statement: Not applicable.

Data Availability Statement: Data is contained within the article.

Conflicts of Interest: The authors declare no conflict of interest.

\section{References}

1. Järbrink, K.; Ni, G.; Sönnergren, H.; Schmidtchen, A.; Pang, C.; Bajpai, R.; Car, J. Prevalence and Incidence of Chronic Wounds and Related Complications: A Protocol for a Systematic Review. Syst. Rev. 2016, 5, 152. [CrossRef]

2. Gottrup, F.; Jørgensen, B.; Karlsmark, T.; Sibbald, R.G.; Rimdeika, R.; Harding, K.; Price, P.; Venning, V.; Vowden, P.; Jünger, M.; et al. Reducing Wound Pain in Venous Leg Ulcers with Biatain Ibu: A Randomized, Controlled Double-Blind Clinical Investigation on the Performance and Safety. Wound Repair Regen. 2008, 16, 615-625. [CrossRef] [PubMed]

3. Price, P.; Fogh, K.; Glynn, C.; Krasner, D.L.; Osterbrink, J.; Sibbald, R.G. Why Combine a Foam Dressing with Ibuprofen for Wound Pain and Moist Wound Healing? Int. Wound J. 2007, 4 (Suppl. 1), 1-3. [CrossRef]

4. Swanson, T.; Angel, D.; Sussman, G.; Cooper, R. Wound Infection in Clinical Practice Update 2016; Wound Infection Institute (WII): 2016. Available online: https://www.woundinfection-institute.com/wp-content/uploads/2017/03/IWII-Wound-infectionin-clinical-practice.pdf (accessed on 3 June 2021).

5. Atiyeh, B.S.; Costagliola, M.; Hayek, S.N.; Dibo, S.A. Effect of Silver on Burn Wound Infection Control and Healing: Review of the Literature. Burns 2007, 33, 139-148. [CrossRef]

6. Jung, W.K.; Koo, H.C.; Kim, K.W.; Shin, S.; Kim, S.H.; Park, Y.H. Antibacterial Activity and Mechanism of Action of the Silver Ion in Staphylococcus Aureus and Escherichia Coli. Appl. Environ. Microbiol. 2008, 74, 2171-2178. [CrossRef] [PubMed]

7. Sripriya, J.; Anandhakumar, S.; Achiraman, S.; Antony, J.J; Siva, D.; Raichur, A.M. Laser Receptive Polyelectrolyte Thin Films Doped with Biosynthesized Silver Nanoparticles for Antibacterial Coatings and Drug Delivery Applications. Int. J. Pharm. 2013, 457, 206-213. [CrossRef] [PubMed]

8. Anandhakumar, S.; Raichur, A.M. Polyelectrolyte/Silver Nanocomposite Multilayer Films as Multifunctional Thin Film Platforms for Remote Activated Protein and Drug Delivery. Acta Biomater. 2013, 9, 8864-8874. [CrossRef] [PubMed]

9. Wang, X.; Cao, W.; Xiang, Q.; Jin, F.; Peng, X.; Li, Q.; Jiang, M.; Hu, B.; Xing, X. Silver Nanoparticle and Lysozyme/Tannic Acid Layer-by-Layer Assembly Antimicrobial Multilayer on Magnetic Nanoparticle by an Eco-Friendly Route. Mater. Sci. Eng. C 2017, 76, 886-896. [CrossRef] [PubMed]

10. Mogrovejo-Valdivia, A.; Rahmouni, O.; Tabary, N.; Maton, M.; Neut, C.; Martel, B.; Blanchemain, N. In Vitro Evaluation of Drug Release and Antibacterial Activity of a Silver-Loaded Wound Dressing Coated with a Multilayer System. Int. J. Pharm. 2019, 556, 301-310. [CrossRef]

11. Aubert-Viard, F.; Martin, A.; Chai, F.; Neut, C.; Tabary, N.; Martel, B. Nicolas Blanchemain Chitosan Finishing Nonwoven Textiles Loaded with Silver and Iodide for Antibacterial Wound Dressing Applications. Biomed. Mater. 2015, 10, 015023. [CrossRef] [PubMed]

12. Burd, A.; Kwok, C.H.; Hung, S.C.; Chan, H.S.; Gu, H.; Lam, W.K.; Huang, L. A Comparative Study of the Cytotoxicity of Silver-Based Dressings in Monolayer Cell, Tissue Explant, and Animal Models. Wound Repair Regen. 2007, 15, 94-104. [CrossRef]

13. Poon, V.K.M.; Burd, A. In Vitro Cytotoxity of Silver: Implication for Clinical Wound Care. Burns 2004, 30, 140-147. [CrossRef] [PubMed] 
14. Abboud, E.C.; Settle, J.C.; Legare, T.B.; Marcet, J.E.; Barillo, D.J.; Sanchez, J.E. Silver-Based Dressings for the Reduction of Surgical Site Infection: Review of Current Experience and Recommendation for Future Studies. Burns 2014, 40, S30-S39. [CrossRef] [PubMed]

15. Jørgensen, B.; Gottrup, F.; Karlsmark, T.; Bech-Thomsen, N.; Sibbald, R.G. Combined Use of an Ibuprofen-Releasing Foam Dressing and Silver Dressing on Infected Leg Ulcers. J. Wound Care 2008, 17, 210-214. [CrossRef] [PubMed]

16. Münter, K.C.; Beele, H.; Russell, L.; Crespi, A.; Gröchenig, E.; Basse, P.; Alikadic, N.; Fraulin, F.; Dahl, C.; Jemma, A.P. Effect of a Sustained Silver-Releasing Dressing on Ulcers with Delayed Healing: The CONTOP Study. J. Wound Care 2006, 15, 199-206. [CrossRef] [PubMed]

17. Morgado, P.I.; Miguel, S.P.; Correia, I.J.; Aguiar-Ricardo, A. Ibuprofen Loaded PVA/Chitosan Membranes: A Highly Efficient Strategy towards an Improved Skin Wound Healing. Carbohydr. Polym. 2017, 159, 136-145. [CrossRef]

18. Jørgensen, B.; Friis, G.J.; Gottrup, F. Pain and Quality of Life for Patients with Venous Leg Ulcers: Proof of Concept of the Efficacy of Biatain-Ibu, a New Pain Reducing Wound Dressing. Wound Repair Regen. 2006, 14, 233-239. [CrossRef]

19. Sibbald, R.G.; Coutts, P.; Fierheller, M.; Woo, K. A Pilot (Real-Life) Randomised Clinical Evaluation of a Pain-Relieving Foam Dressing: (Ibuprofen-Foam versus Local Best Practice). Int. Wound J. 2007, 4 (Suppl. 1), 16-23. [CrossRef]

20. Agarwal, A.; Nelson, T.B.; Kierski, P.R.; Schurr, M.J.; Murphy, C.J.; Czuprynski, C.J.; McAnulty, J.F.; Abbott, N.L. Polymeric Multilayers That Localize the Release of Chlorhexidine from Biologic Wound Dressings. Biomaterials 2012, 33, 6783-6792. [CrossRef]

21. Maver, T.; Gradišnik, L.; Kurečič, M.; Hribernik, S.; Smrke, D.M.; Maver, U.; Kleinschek, K.S. Layering of Different Materials to Achieve Optimal Conditions for Treatment of Painful Wounds. Int. J. Pharm. 2017, 529, 576-588. [CrossRef]

22. Shukla, A.; Fuller, R.C.; Hammond, P.T. Design of Multi-Drug Release Coatings Targeting Infection and Inflammation. J. Control. Release 2011, 155, 159-166. [CrossRef] [PubMed]

23. Aubert-Viard, F.; Mogrovejo-Valdivia, A.; Tabary, N.; Maton, M.; Chai, F.; Neut, C.; Martel, B.; Blanchemain, N. Evaluation of Antibacterial Textile Covered by Layer-by-Layer Coating and Loaded with Chlorhexidine for Wound Dressing Application. Mater. Sci. Eng. C 2019, 100, 554-563. [CrossRef]

24. Shukla, A.; Fang, J.C.; Puranam, S.; Hammond, P.T. Release of Vancomycin from Multilayer Coated Absorbent Gelatin Sponges. J. Control. Release 2012, 157, 64-71. [CrossRef] [PubMed]

25. Decher, G. Fuzzy Nanoassemblies: Toward Layered Polymeric Multicomposites. Science 1997, 277, 1232-1237. [CrossRef]

26. Zhou, B.; Hu, Y.; Li, J.; Li, B. Chitosan/Phosvitin Antibacterial Films Fabricated via Layer-by-Layer Deposition. Int. J. Biol. Macromol. 2014, 64, 402-408. [CrossRef] [PubMed]

27. Zhou, B.; Li, Y.; Deng, H.; Hu, Y.; Li, B. Antibacterial Multilayer Films Fabricated by Layer-by-Layer Immobilizing Lysozyme and Gold Nanoparticles on Nanofibers. Colloids Surf. B Biointerfaces 2014, 116, 432-438. [CrossRef] [PubMed]

28. Gomes, A.P.; Mano, J.F.; Queiroz, J.A.; Gouveia, I.C. Incorporation of Antimicrobial Peptides on Functionalized Cotton Gauzes for Medical Applications. Carbohydr. Polym. 2015, 127, 451-461. [CrossRef]

29. Croisier, F.; Jérôme, C. Chitosan-Based Biomaterials for Tissue Engineering. Eur. Polym. J. 2013, 49, 780-792. [CrossRef]

30. Jayakumar, R.; Prabaharan, M.; Sudheesh Kumar, P.T.; Nair, S.V.; Tamura, H. Biomaterials Based on Chitin and Chitosan in Wound Dressing Applications. Biotechnol. Adv. 2011, 29, 322-337. [CrossRef]

31. Bano, I.; Arshad, M.; Yasin, T.; Ghauri, M.A.; Younus, M. Chitosan: A Potential Biopolymer for Wound Management. Int. J. Biol. Macromol. 2017, 102, 380-383. [CrossRef]

32. Balan, V.; Verestiuc, L. Strategies to Improve Chitosan Hemocompatibility: A Review. Eur. Polym. J. 2014, 53, 171-188. [CrossRef]

33. Patrulea, V.; Ostafe, V.; Borchard, G.; Jordan, O. Chitosan as a Starting Material for Wound Healing Applications. Eur. J. Pharm. Biopharm. 2015, 97, 417-426. [CrossRef] [PubMed]

34. Lee, Y.-H.; Chang, J.-J.; Yang, M.-C.; Chien, C.-T.; Lai, W.-F. Acceleration of Wound Healing in Diabetic Rats by Layered Hydrogel Dressing. Carbohydr. Polym. 2012, 88, 809-819. [CrossRef]

35. Han, F.; Dong, Y.; Song, A.; Yin, R.; Li, S. Alginate/Chitosan Based Bi-Layer Composite Membrane as Potential Sustained-Release Wound Dressing Containing Ciprofloxacin Hydrochloride. Appl. Surf. Sci. 2014, 311, 626-634. [CrossRef]

36. Brewster, M.E.; Loftsson, T. Cyclodextrins as Pharmaceutical Solubilizers. Adv. Drug Deliv. Rev. 2007, 59, 645-666. [CrossRef] [PubMed]

37. Blanchemain, N.; Karrout, Y.; Tabary, N.; Bria, M.; Neut, C.; Hildebrand, H.F.; Siepmann, J.; Martel, B. Comparative Study of Vascular Prostheses Coated with Polycyclodextrins for Controlled Ciprofloxacin Release. Carbohydr. Polym. 2012, 90, 1695-1703. [CrossRef]

38. Flores, C.; Lopez, M.; Tabary, N.; Neut, C.; Chai, F.; Betbeder, D.; Herkt, C.; Cazaux, F.; Gaucher, V.; Martel, B.; et al. Preparation and Characterization of Novel Chitosan and $\beta$-Cyclodextrin Polymer Sponges for Wound Dressing Applications. Carbohydr. Polym. 2017, 173, 535-546. [CrossRef]

39. Ouerghemmi, S.; Degoutin, S.; Tabary, N.; Cazaux, F.; Maton, M.; Gaucher, V.; Janus, L.; Neut, C.; Chai, F.; Blanchemain, N.; et al. Triclosan Loaded Electrospun Nanofibers Based on a Cyclodextrin Polymer and Chitosan Polyelectrolyte Complex. Int. J. Pharm. 2016, 513, 483-495. [CrossRef]

40. Garcia-Fernandez, M.J.; Maton, M.; Benzine, Y.; Tabary, N.; Baptiste, E.J.; Gargouri, M.; Bria, M.; Blanchemain, N.; Karrout, Y. Ciprofloxacin Loaded Vascular Prostheses Functionalized with Poly-Methylbeta-Cyclodextrin: The Importance of in Vitro Release Conditions. J. Drug Deliv. Sci. Technol. 2019, 53, 101166. [CrossRef] 
41. Vermet, G.; Degoutin, S.; Chai, F.; Maton, M.; Flores, C.; Neut, C.; Danjou, P.E.; Martel, B.; Blanchemain, N. Cyclodextrin Modified PLLA Parietal Reinforcement Implant with Prolonged Antibacterial Activity. Acta Biomater. 2017, 53, 222-232. [CrossRef]

42. Vermet, G.; Degoutin, S.; Chai, F.; Maton, M.; Bria, M.; Danel, C.; Hildebrand, H.F.; Blanchemain, N.; Martel, B. Visceral Mesh Modified with Cyclodextrin for the Local Sustained Delivery of Ropivacaine. Int. J. Pharm. 2014, 476, 149-159. [CrossRef]

43. Jansook, P.; Ogawa, N.; Loftsson, T. Cyclodextrins: Structure, Physicochemical Properties and Pharmaceutical Applications. Int. J. Pharm. 2018, 535, 272-284. [CrossRef] [PubMed]

44. Tabary, N.; Garcia-Fernandez, M.J.; Danède, F.; Descamps, M.; Martel, B.; Willart, J.-F. Determination of the Glass Transition Temperature of Cyclodextrin Polymers. Carbohydr. Polym. 2016, 148, 172-180. [CrossRef]

45. Palomino-Durand, C.; Lopez, M.; Cazaux, F.; Martel, B.; Blanchemain, N.; Chai, F. Influence of the SolubleInsoluble Ratios of Cyclodextrins Polymers on the Viscoelastic Properties of Injectable ChitosanBased Hydrogels for Biomedical Application. Polymers 2019, 11, 214. [CrossRef] [PubMed]

46. Kersani, D.; Mougin, J.; Lopez, M.; Degoutin, S.; Tabary, N.; Cazaux, F.; Janus, L.; Maton, M.; Chai, F.; Sobocinski, J.; et al. Stent Coating by Electrospinning with Chitosan/Poly-Cyclodextrin Based Nanofibers Loaded with Simvastatin for Restenosis Prevention. Eur. J. Pharm. Biopharm. 2020, 150, 156-167. [CrossRef]

47. Pérez-Anes, A.; Gargouri, M.; Laure, W.; Van Den Berghe, H.; Courcot, E.; Sobocinski, J.; Tabary, N.; Chai, F.; Blach, J.-F.; Addad, A.; et al. Bioinspired Titanium Drug Eluting Platforms Based on a Poly- $\beta$-Cyclodextrin-Chitosan Layer-by-Layer Self-Assembly Targeting Infections. ACS Appl. Mater. Interfaces 2015, 7, 12882-12893. [CrossRef] [PubMed]

48. Weltrowski, M.; Morcellet, M.; Martel, B. Cyclodextrin Polymers and/or Cyclodextrin Derivatives with Complexing Properties and Ion-Exchange Properties and Method for the Production Thereof. U.S. Patent 6,660,804, 9 December 2003.

49. Martin, A.; Tabary, N.; Chai, F.; Leclercq, L.; Junthip, J.; Aubert-Viard, F.; Neut, C.; Weltrowski, M.; Blanchemain, N.; Martel, B. Build-up of an Antimicrobial Multilayer Coating on a Textile Support Based on a Methylene Blue-Poly(Cyclodextrin) Complex. Biomed. Mater. 2013, 8, 065006. [CrossRef] [PubMed]

50. Martin, A.; Tabary, N.; Leclercq, L.; Junthip, J.; Degoutin, S.; Aubert-Viard, F.; Cazaux, F.; Lyskawa, J.; Janus, L.; Bria, M.; et al. Multilayered Textile Coating Based on a $\beta$-Cyclodextrin Polyelectrolyte for the Controlled Release of Drugs. Carbohydr. Polym. 2013, 93, 718-730. [CrossRef]

51. Jean-Baptiste, E.; Blanchemain, N.; Neut, C.; Chai, F.; Maton, M.; Martel, B.; Hildebrand, H.; Haulon, S. Evaluation of the Anti-Infectious Properties of Polyester Vascular Prostheses Functionalised with Cyclodextrin. J. Infect. 2014, 68, 116-124. [CrossRef]

52. Blanchemain, N.; Karrout, Y.; Tabary, N.; Neut, C.; Bria, M.; Siepmann, J.; Hildebrand, H.F.; Martel, B. Methyl- $\beta$-Cyclodextrin Modified Vascular Prosthesis: Influence of the Modification Level on the Drug Delivery Properties in Different Media. Acta Biomater. 2011, 7, 304-314. [CrossRef]

53. Decher, G.; Eckle, M.; Schmitt, J.; Struth, B. Layer-by-Layer Assembled Multicomposite Films. Curr. Opin. Colloid Interface Sci. 1998, 3, 32-39. [CrossRef]

54. Higuchi, T.; Connors, K. Advances in Analytical Chemistry and Instrumentation. Adv. Anal. Chem. Instrum. 1965, 4, 117-212.

55. Saokham, P.; Muankaew, C.; Jansook, P.; Loftsson, T. Solubility of Cyclodextrins and Drug/Cyclodextrin Complexes. Molecules 2018, 23, 1161. [CrossRef]

56. Trotta, F.; Zanetti, M.; Cavalli, R. Cyclodextrin-Based Nanosponges as Drug Carriers. Beilstein J. Org. Chem. 2012, 8, 2091-2099. [CrossRef]

57. García-Fernández, M.J.; Tabary, N.; Martel, B.; Cazaux, F.; Oliva, A.; Taboada, P.; Concheiro, A.; Alvarez-Lorenzo, C. Poly(Cyclo)Dextrins as Ethoxzolamide Carriers in Ophthalmic Solutions and in Contact Lenses. Carbohydr. Polym. 2013, 98, 1343-1352. [CrossRef]

58. Pereva, S.; Sarafska, T.; Bogdanova, S.; Spassov, T. Efficiency of “Cyclodextrin-Ibuprofen” Inclusion Complex Formation. J. Drug Deliv. Sci. Technol. 2016, 35, 34-39. [CrossRef]

59. Di Cagno, M.; Stein, P.C.; Skalko-Basnet, N.; Brandl, M.; Bauer-Brandl, A. Solubilization of Ibuprofen with $\beta$-Cyclodextrin Derivatives: Energetic and Structural Studies. J. Pharm. Biomed. Anal. 2011, 55, 446-451. [CrossRef] [PubMed]

60. Herbois, R.; Noël, S.; Léger, B.; Tilloy, S.; Menuel, S.; Addad, A.; Martel, B.; Ponchel, A.; Monflier, E. Ruthenium-Containing $\beta$-Cyclodextrin Polymer Globules for the Catalytic Hydrogenation of Biomass-Derived Furanic Compounds. Green Chem. 2015, 17, 2444-2454. [CrossRef]

61. Kfoury, M.; Landy, D.; Auezova, L.; Greige-Gerges, H.; Fourmentin, S. Effect of Cyclodextrin Complexation on Phenylpropanoids' Solubility and Antioxidant Activity. Beilstein J. Org. Chem. 2014, 10, 2322-2331. [CrossRef]

62. Steffansen, B.; Herping, S.P.K. Novel Wound Models for Characterizing Ibuprofen Release from Foam Dressings. Int. J. Pharm. 2008, 364, 150-155. [CrossRef]

63. Blanchemain, N.; Haulon, S.; Boschin, F.; Traisnel, M.; Morcellet, M.; Martel, B.; Hildebrand, H.F. Vascular Prostheses with Controlled Release of Antibiotics Part 2. In Vitro Biological Evaluation of Vascular Prostheses Treated by Cyclodextrins. Biomol. Eng. 2007, 24, 143-148. [CrossRef] [PubMed] 